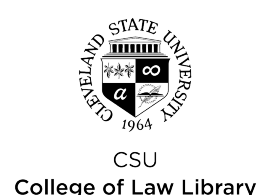

Cleveland State University

College of Law Library

\title{
EngagedScholarship@CSU
}

\section{Express Yourself: Striking a Balance Between Silence and Active, Purposive Opposition Under Title VII's Anti-Retaliation Provision}

Matthew W. Green Jr.

Cleveland State University, m.w.green@csuohio.edu

Follow this and additional works at: https://engagedscholarship.csuohio.edu/fac_articles

Part of the Civil Rights and Discrimination Commons, and the Labor and Employment Law Commons How does access to this work benefit you? Let us know!

Original Citation

Matthew Green, Express Yourself: Striking a Balance Between Silence and Active, Purposive Opposition Under Title VII's Anti-Retaliation Provision, 28 Hofstra Labor and Employment Law Journal 107 (2010)

This Article is brought to you for free and open access by the Faculty Scholarship at EngagedScholarship@CSU. It has been accepted for inclusion in Law Faculty Articles and Essays by an authorized administrator of EngagedScholarship@CSU. For more information, please contact research.services@law.csuohio.edu. 


\section{HEINONLINE}

Citation: 28 Hofstra Lab. \& Emp. L. J. 1072010

Content downloaded/printed from

HeinOnline (http://heinonline.org)

Fri Apr 27 15:40:39 2012

-- Your use of this HeinOnline PDF indicates your acceptance of HeinOnline's Terms and Conditions of the license agreement available at http://heinonline.org/HOL/License

-- The search text of this PDF is generated from uncorrected OCR text.

-- To obtain permission to use this article beyond the scope of your HeinOnline license, please use:

https://www.copyright.com/ccc/basicSearch.do?

\&operation $=$ go\&search Type $=0$

\&lastSearch $=$ simple\&all=on\&titleOrStdNo=1189-3332 


\title{
EXPRESS YOURSELF: STRIKING A BALANCE BETWEEN SILENCE AND ACTIVE, PURPOSIVE OPPOSITION UNDER TITLE VII'S ANTI- RETALIATION PROVISION
}

\author{
Matthew W. Green, Jr.* \\ "When one door closes another opens; but we often look so long \\ and so regretfully upon the closed door that we do not see the one which \\ has opened for us." - Alexander Graham Bell
}

\section{INTRODUCTION}

What does the word "oppose" mean? The U.S. Supreme Court addressed the ostensibly simple question in Crawford v. Metropolitan Government of Nashville \& Davidson County, Tennessee. To date, Crawford is the Roberts Court's most recent employment discrimination decision involving retaliation. ${ }^{2}$ In Crawford, the Court broadly

* Assistant Professor, Cleveland-Marshall College of Law; LL.M., Columbia University, Harlan Fiske Stone Scholar; J.D., University of Baltimore School of Law, Magna Cum Laude; B.A., University of Maryland, College Park; law clerk to the Hon. Eric L. Clay, U.S. Court of Appeals for the Sixth Circuit, 2001-2002 and the Hon. Deborah K. Chasanow, U.S. District Court for the District of Maryland, 2000-2001. I owe very special thanks to Professor Michael Hayes at the University of Baltimore School of Law for his helpful criticism of earlier drafts. I would also like to thank my colleague Professor Browne C. Lewis at Cleveland-Marshall College of Law for her comments and encouragement regarding this article as well as research assistants Jill Battagline and Tyessa V. Howard for their hard work.

1. 129 S. Ct. 846, 850-52 (2009).

2. See id. The Roberts Court has decided four retaliation cases, and in each the plaintiff prevailed. See id.; CBOCS West, Inc. v. Humphries, 128 S. Ct. 1951, 1954, 1961 (2008); GomezPerez v. Potter, 128 S. Ct. 1931, 1935 (2008); Burlington N. \& Santa Fe Ry. Co. v. White, 548 U.S. 53,73 (2006). The Court also has granted certiorari in another case involving retaliation for the 2010 term. See Thompson v. N. Am. Stainless, LP, 567 F.3d 804 (6th Cir. 2009) (en banc), cert. granted, 130 S. Ct. 3542 (2010). The Court's recent decisions have resulted in increased scholarly attention on retaliation. See, e.g., Deborah L. Brake, Retaliation, 90 MINN. L. REV. 18, 19 (2005) (observing that legal scholarship focuses mainly on bias rather than retaliation); Brianne J. Gorod, Rejecting "Reasonableness": A New Look at Title VII's Anti-Retaliation Provision, 56 AM. U. L. REV. 1469, 1470 (2007) (noting that previously, Title VII's anti-retaliation provisions were underappreciated by commentators and courts, and not receiving the same amount of attention given 
interpreted the opposition clause under Title VII's anti-retaliation provisions. ${ }^{3}$ That clause bars discrimination because, inter alia, an employee or applicant "has opposed" an employment practice made unlawful by Title VII. ${ }^{4}$ The Court proclaimed in Crawford that the common everyday meaning of the term oppose encompasses "to be hostile or adverse to, as in opinion." VII contemplate opinion opposition? The answer is far from clear. In his concurring opinion in Crawford, Justice Alito was concerned that the Court's "dicta" of opposition by "opinion" could be taken as recognizing "silent opposition." Justice Alito's concern regarding silent opposition was prescient. After Crawford, some lower court judges among others have discussed the viability of silent opposition.

to the statute as a whole); Alex B. Long, The Troublemaker's Friend: Retaliation Against Third Parties and the Right of Association in the Workplace, 59 FLA. L. REV. 931, 936 (2007) (contending, among other things, that Burlington Northern \& Santa Fe should result in a broader interpretation of Title VII's anti-retaliation provisions); Michael Selmi, The 2007-2008 Term: The Government Changes Its Tune and the Supreme Court Takes a Pragmatic Turn, 12 EMP. RTS. \& EMP. POL'Y J. 161, 165 (2008) (describing the recent trend in retaliation as evidence of a pragmatism within the Court); Michael J. Zimmer, A Pro-Employee Supreme Court?: The Retaliation Decisions, 60 S.C. L. REV. 917, 918 (2009) (describing a pro-employee stance that the Court has taken in retaliation cases, and how this recent trend is evidence of a pragmatism within the Court).

3. See Crawford, $129 \mathrm{~S}$. Ct. at 850-52. Title VII's anti-retaliation provision contains two clauses that protect against unlawful discrimination: the opposition clause and the participation clause. Id.; see Title VII of the Civil Rights Act of 1964, 42 U.S.C. $\$ 2000 \mathrm{e}-3$ (a) (2006). This article focuses on the opposition clause as it considers, among other things, whether silent opposition, a concept ostensibly recognized as a form of opposition in Crawford, is an actionable form of opposition under Title VII. See $129 \mathrm{~S}$. Ct. at 851 ; see, e.g., Thompson v. N. Am. Stainless, LP, 567 F.3d 804, 823-24 (6th Cir. 2009) (en banc) (Moore, J., dissenting), cert. granted, 130 S. Ct. 3542 (2010); see also discussion infra Part III.

4. See 42 U.S.C. $\S 2000 \mathrm{e}-3$ (a). For the sake of brevity, this article uses the term "employee" when discussing the reach of the opposition clause. However, the statute bars employers from discriminating against both employees or applicants. See id.

5. Crawford, $129 \mathrm{~S}$. Ct. at 850 .

6. Id. at 854 (Alito, J., concurring).

7. See Thompson, 567 F.3d at 818 (majority opinion). In Thompson, an en banc case from the U.S. Court of Appeals for the Sixth Circuit, the dissenting opinions cited Crawford as potentially recognizing silent opposition to support the retaliation claim of a plaintiff who was fired after his fiancé complained of sex discrimination. See, e.g., id. at 818-19 (Martin, J., dissenting) (relying on Crawford to demonstrate that the term "oppose" includes "silent opposition of everything from gay marriage to the death penalty, without requiring anyone to shout it from the rooftops"). According to the dissenting judges, under Crawford's broad understanding of opposition, the plaintiff should have been allowed to argue that by virtue of his relationship, his employer could have reasonably inferred his opposition to his fiancé's discrimination and fired him because of it. See id. at 818-20; see also id. at 823-24 (Moore, J., dissenting); DIANNE AVERY, Maria L. Ontiveros, Roberto L. Corrada, Michael SElmi \& Melissa Hart, EMPloyment 
This article considers and rejects that Crawford should be read as opening the door to silent opposition. Crawford did recognize that one of the many meanings of the term oppose is to be hostile to as in opinion. ${ }^{8}$ As the Court has stated elsewhere, however, "[a] word in a statute [does not necessarily] extend to the outer limits of its definitional possibilities." Relying on principles of statutory interpretation, this article demonstrates that silent opposition is inconsistent with the language, context, structure and purposes of Title VII and should not be counted among the types of opposition recognized under the statute. ${ }^{10}$

Although the article determines that Crawford should not open the door to silent opposition, it also examines the type of opposition consistent with the plain language of Title VII for which Crawford did open doors. It does so specifically in response to Justice Alito's concerns regarding silent opposition. To quell concerns regarding silent opposition (including possibly holding employers liable for retaliation when employees have never expressed a word of opposition to employers), Justice Alito proposed that to be actionable, Title VII opposition should contain an active, purposive requirement. ${ }^{11}$ Under this standard, it is not enough that the employee opposes the employer's alleged discrimination or that the opposition, in fact, reaches the employer's attention. It requires that the employee oppose discrimination for a specific purpose, including ending, remediating or correcting the discrimination, and also requires that the employee intend to bring the opposition to the employer's attention for these purposes. ${ }^{12}$

DisCRIMINATION LAW: CASES AND MATERIALS ON EQUALITY IN THE WORKPLACE 173 (8th ed. 2010) (noting that Crawford "seems to suggest that silent opposition to unlawful discrimination can sometimes be protected"; but also noting that Justice Scalia, who joined the majority opinion, stated during oral argument in Crawford "that he would have an issue if the Court's reading [of the antiretaliation provision] meant silent opposition would be protected"); John B. Lough, Jr., Employers Still Cannot Retaliate: Crawford v. Metropolitan Government of Nashville, 13 Haw. B. J. 4, 10 (2009) (explaining that Crawford defined opposition as to be adverse to as in opinion and may set the stage for silent opposition). This article does not address the issue of whether a Title VII plaintiff may assert a claim for retaliation based on the opposition conduct of another employee. Rather, it addresses whether silent or opinion opposition generally is cognizable under the statute.

8. Crawford, 129 S. Ct. at 850 .

9. Dolan v. U.S. Postal Serv., 546 U.S. 481, 486 (2006).

10. See discussion infra Part III.

11. See Crawford, 129 S. Ct. at 854 (Alito, J., concurring).

12. See id; see also Pitrolo v. Cnty. of Buncombe, N.C., No. 07-2145, 2009 WL 1010634, at *3 (4th Cir. Mar. 11, 2009) (applying active, purposive standard and affirming dismissal of retaliation claim where employee did not intend to bring her grievance to her employer's attention although employer undisputedly learned of it). 
The following factual scenario is a composite of cases employing the active, purposive standard and demonstrates the problems that arise by adopting this standard. ${ }^{13}$

Miriam is one of two female employees in the fifteen-employee tech department of a large medical device testing company. She has contemplated quitting several times. Her supervisor Connor is the problem. At first, Connor would compliment her almost daily on her hair and make-up. While it made her uncomfortable, she thought she could handle it. Besides she was relatively new to the company, Connor was considered a "rock star," and she did not want any trouble. Things soon got worse. Once he walked up behind her, put his arm around her waist, and told her he could make her life pleasant or unpleasant, "her choice." When she asked him what he meant, he stroked her breast and said "I think you know." Over the next couple of months, he made similar comments, groped her rear and breasts repeatedly and once forcibly tried to kiss her. He also told her not to wear pantyhose anymore as he liked the look of her bare legs, and more than once he tried to raise her skirt. Miriam didn't want to lose her job, so although she knew about the company's sexual harassment policy, she decided not to report the harassment to the human resources department as the policy required. She had a better idea. She had seen a notice for a position in another department, which would have meant a promotion for her. She knew she was qualified for the job and thought if she could get it, her problems would be solved. However, because of the stress of the Connor incidents, about two or three months after Connor's initial comments, she complained about what was going on at work to her coworker, Sylvia Monroe, a supervisor who works in another department. Sylvia took it upon herself to contact human resources and complain on Miriam's behalf. The company began an investigation into the matter. After the allegations came to light, Miriam immediately felt shunned by coworkers and made to feel like the entire matter was her fault. She also did not receive the promotion and believed it was in retaliation for her harassment complaint.

13. See Pitrolo, 2009 WL 1010634 , at *3 (holding that plaintiff's retaliation claim failed as she did not act purposively when she complained about sex discrimination to her father with no intention of telling management herself); Ackel v. Nat'l Commc'ns, Inc., 339 F.3d 376, 385 (5th Cir. 2003) (holding that plaintiff who alleged sexual harassment and retaliation had not engaged in protected activity for purposes of a retaliation claim after complaining only to a coworker with no intent to notify management). 
Under the active, purposive standard, an employee in Miriam's position would be unable to assert a viable retaliation claim regarding the failed promotion. Although her employer undisputedly learned of her complaint, she failed to act purposively in lodging the complaint. ${ }^{14}$ Adopting an active, purposive standard of opposition, some courts have rejected retaliation claims when, as in Miriam's case, the opposition is indirectly communicated and not at the behest of the victim. ${ }^{15}$

Under a plain reading of the statute, however, it should not matter how an employer learns of the opposition, directly or indirectly, or whether the employee intends to bring the opposition to the employer's attention. What matters is whether the opposition reaches the employer's attention and whether the employer discriminates on the basis of the opposition. Thus, opposition that is indirectly and unintentionally expressed to an employer is no less actionable than directly expressed, intentional opposition.

The courts requiring purposive opposition have engaged in a cramped reading of the statute that is inconsistent with its language, structure, and purposes. By its terms, the statute requires only that employees oppose unlawful employment practices. ${ }^{16}$ It does not require they do so for any particular purpose. ${ }^{17}$ From a normative perspective, the article contends that whenever an employee expresses, intentionally or otherwise, what may reasonably be interpreted or inferred as opposition to an alleged unlawful employment practice, and the employer retaliates because of that expression, the latter has violated the statute's anti-retaliation provision. The article, therefore, proposes a standard of expressive opposition. Such opposition may be manifested in any number of ways--words, action, or inaction -and requires only that opposition may be reasonably inferred from such expression. The article demonstrates that such a standard is consistent with the language and structure of Title VII and comports with Crawford's broad reading of the statute.

The active, purposive standard is thus ill-advised for several reasons. It ignores that opposition may be unintentional. The Equal Employment Opportunity Commission ("EEOC") has long recognized

14. As explained later, Miriam's harassment claim would likely also fail as she did not follow her employer's reporting procedure, and a court would likely not consider her complaint prompt. See discussion infra Part IV.C.

15. See Pitrolo, 2009 WL 1010634, at *3; Ackel, 339 F.3d 376, 385.

16. See Title VII of the Civil Rights Act of 1964, 42 U.S.C. $\$ 2000 \mathrm{e}-3$ (a) (2006).

17. See id. 
that an employee may engage in conduct that an employer interprets as opposition to employment discrimination even where the employee did not intend to oppose discrimination. ${ }^{18}$ Lower courts also have recognized that when an employer discriminates on the basis of what it interprets as opposition by an employee, the employer violates Title VII's anti-retaliation provision. ${ }^{19}$ The employee's intent is irrelevant. ${ }^{20}$ However, the employer's intent to discriminate is the critical issue, and if the employer discriminates because it interprets certain conduct as opposition, the statute requires no more to impose liability. ${ }^{21}$

The standard would also exacerbate extant gaps in protection in workplace harassment law. Miriam's situation is a classic example. As explained later, because of the manner in which the courts have interpreted workplace harassment law, a plaintiff in Miriam's position would be unlikely to prevail on a sexual harassment claim. ${ }^{22}$ The result is grounded in the way courts have interpreted the affirmative defense set forth in Burlington Industries, Inc. v. Ellerth ${ }^{23}$ and Faragher v. City of Boca Raton. ${ }^{24}$ That defense allows employers to escape liability or limit damages in certain cases where the perpetrator of harassment is a supervisory employee. ${ }^{25}$ In these circumstances, a court would likely find that Miriam failed to act reasonably to avoid harm because she failed to use her employer's complaint procedure, and when she did complain, she did so more than two months after the first incident of harassment. ${ }^{26}$ The problem is that out of fear of retaliation most victims of workplace harassment do not formally complain as an initial response to harassment. ${ }^{27}$ The Burlington-Faragher affirmative defense's disregard of that workplace reality is one of the reasons scholars have

18. See discussion infra Part IV.B.

19. See discussion infra Part IV.B; see also Fogleman v. Mercy Hosp., Inc., 283 F.3d 561, 567, 571-72 (3rd Cir. 2002) (holding that a plaintiff that is either perceived to have engaged in protected activity, or has actually engaged in protected activity under the Age Discrimination in Employment Act ("ADEA"), is subject to the same retaliation claim analysis as in Title VII); Grosso v. City Univ. of N.Y., No. 03 Civ. 2619NRB, 2005 WL 627644, at *3 (S.D.N.Y. Mar. 16, 2005) (employing same analysis as Fogleman, but directly to Title VII claim).

20. Grosso, 2005 WL 627644 , at *3.

21. See 42 U.S.C. $\$ 2000 \mathrm{e}-3$ (a).

22. See discussion infra Part V.

23. 524 U.S. 742, 765 (1998).

24. 524 U.S. $775,777-78$ (1998).

25. See Burlington, 524 U.S. 742 at 765 ; see also Faragher, 524 U.S. at 778.

26. See discussion infra Part IV.C.

27. See Crawford v. Metro. Gov't of Nashville \& Davidson Cnty., Tenn., $129 \mathrm{~S}$. Ct. at 852 (citing Deborah L. Brake, Retaliation, 90 MINN. L. REV. 18, 20 (2005)). 
criticized the standard as creating unnecessary gaps in protection for victims of unlawful workplace discrimination. ${ }^{28}$ The active, purposive standard would compound such gaps. ${ }^{29}$ Not only would an employee in Miriam's position likely have no viable claim for harassment, but because her opposition was non-purposive, her retaliation claim regarding her promotion would fail as well. The active, purposive standard, therefore, would serve as one more hurdle for victims of workplace harassment to obtain relief under the statute if, after their harassment comes to light, they encounter retaliation.

Finally, the active, purposive standard is premised on irrelevant policy concerns. The primary impetus for this standard appears to stem from the flux of retaliation claims in recent years. ${ }^{30}$ It is true that according to EEOC charge statistics, retaliation charges have proliferated in the past several years. ${ }^{31}$ However, that is a concern for Congress, which implemented a broadly worded anti-retaliation provision to protect employees who, among other things, oppose unlawful workplace discrimination. ${ }^{32}$ Courts should not be in the business of promulgating prophylactic rules contrary to the plain language of Title VII that narrows rights Congress gave.

In short, although the article determines that while Crawford should not open the door to silent opposition, the active, purposive requirement that Justice Alito championed and that some courts pre- and postCrawford have adopted goes too far the other way. ${ }^{33}$ There is a swath of

28. See Deborah L. Brake \& Joanna L. Grossman, The Failure of Title VII As a RightsClaiming Statute, 86 N.C. L. REV. 859, 880 (2008). Courts have found it unreasonable under the Burlington-Faragher affirmative defense for employees to complain to the wrong person under a company's harassment policy, to go directly to the EEOC or a union representative to complain, to provide insufficient information for the employer to conduct an investigation, or to fail to cooperate in an investigation. Id. According to the authors, the defense is one of the reasons that Title VIl fails as a system for claiming non-discrimination rights. Id. Anne Lawton, Operating in an Empirical Vacuum: The Ellerth and Faragher Affirmative Defense, 13 COLUM. J. GENDER \& L. 197,215 (2004) (noting that a number of federal courts hold that an employee who delays reporting harassment or who fails to use the employer's reporting procedure designated in its harassment policy fails to act reasonably. The courts do not address the reasons for the employee's behavior in light of case facts); Long, supra note 2, at 953 (explaining that courts hold that a failure to use an employer's internal mechanism for reporting harassment is unjustified under the BurlingtonFaragher affirmative defense).

29. See Brake \& Grossman, supra note 28 , at 897,898 .

30. Crawford, 129 S. Ct. 846, 854 (2009) (Alito, J., concurring).

31. See Charge Statistics FY 1997 Through FY 2009, U.S. EQUAL EMPL'T OPPORTUNITY COMM'N, http://www.eeoc.gov/eeoc/statistics/enforcement/charges.cfm (last visited Dec. 22, 2010).

32. See Title VII of the Civil Rights Act of 1964, 42 U.S.C. $\$ 2000 \mathrm{e}-3$ (a) (2006)

33. See infra Part III.B.3.b. 
opposition conduct that stands between silence and the standard that Justice Alito and some courts advocate. ${ }^{34}$ This article explores where that line should be drawn.

The article is set forth in five parts. Part II briefly explains the opposition clause and discusses Crawford. Part III examines the language, context, structure and purposes of Title VII and concludes that the statute's anti-retaliation provision does not contemplate silent opposition. Part IV sets forth the expressive form of opposition that is consistent with the language of Title VII. Such opposition falls short of the active, purposive opposition Justice Alito and some lower courts have championed but requires more than silence. ${ }^{35}$ Part IV further explains why the active, purposive standard should be rejected as a threshold for actionable opposition under Title VII. Part V applies the standard of expressive opposition proposed here to the hypothetical set forth previously involving Miriam, in which her opposition conduct is not silent but also would fail to meet the onerous active, purposive standard.

\section{RETALIATION: CRAWFORD AND ITS DICTA OF OPPOSITION BY OPINION ${ }^{36}$}

\section{A. The Limited Nature of the Opposition Clause}

Title VII provides:

It shall be an unlawful employment practice for an employer to discriminate against any of his employees or applicants for employment . . . because he has opposed any practice made an unlawful employment practice [under Title VII], or because he has made a charge, testified, assisted, or participated in any manner in an investigation, proceeding, or hearing under this subchapter. ${ }^{37}$

Title VII's anti-retaliation clause protects an individual who has opposed an unlawful employment practice or who has made a charge,

34. See discussion infra Part III.A.

35. See discussion infra Part IV.

36. While this article focuses on the opposition clause (as did Crawford), Part A briefly explains the participation and opposition clauses contained in Title VII's anti-retaliation provision and when each clause has been held to apply. Part B discusses Crawford and its interpretation of the opposition clause.

37. 42 U.S.C. $\$ 2000 \mathrm{e}-3(\mathrm{a})$ (emphasis added). 
testified, assisted, or participated in any manner in a Title VII "investigation, proceeding, or hearing." A plaintiff does not have to show that he or she opposed a practice that was actually unlawful under Title VII, but typically, that he or she had a reasonable, good-faith belief that the practice was unlawful. ${ }^{39}$ Most lay people are not versed in the law, and courts recognized early on the problems that would inure were Title VII literally interpreted to protect employees against retaliation only if they prove the employer conduct about which they complained was actually unlawful under the statute. ${ }^{40}$

The courts that have decided the issue have held that employees who file a charge of discrimination with an administrative agency are protected by Title VII's anti-retaliation participation clause. ${ }^{41}$

38. Id.

39. See, e.g., Higgins v. New Balance Athletic Shoe, Inc., 194 F.3d 252, $261-62$ (1st Cir. 1999) (explaining that Title VII does not require that the activity complained of actually be unlawful only that the employee reasonably believed that it was unlawful and communicates that belief to the employer in good faith); Payne v. McLemore's Wholesale \& Retail Stores, 654 F.2d 1130, 1140 \& n.11 (5th Cir. 1981) ("To effectuate the policies of Title VII and to avoid the chilling effect that would otherwise arise, we are compelled to conclude that a plaintiff can establish a prima facie case of retaliatory discharge under the opposition clause . . . if he shows that he had a reasonable belief that the employer was engaged in unlawful employment practices.") (noting that other courts require the reasonable belief be held in "good faith"); Sias v. City Demonstration Agency, 588 F.2d 692, 695 (9th Cir. 1978) (employee is protected under the opposition clause if he reasonably believes discrimination has occurred and opposes it, even if he is later mistaken).

40. See Payne, 654 F.2d at 1140 ("To effectuate the policies of Title VII and to avoid the chilling effect that would otherwise arise, we are compelled to conclude that a plaintiff can establish a prima facie case of retaliatory discharge under the opposition clause ... if he shows that he had a reasonable belief that the employer was engaged in unlawful employment practices" and noting that other courts require the reasonable belief be held in "good faith"). While the standard was promulgated to assist plaintiffs, scholars have increasingly criticized the standard as some courts have narrowly interpreted the instances when an employee has a good faith reasonable belief that discrimination exists. See Long, supra note 2, at 955 (noting that some courts have held an employee's reasonable belief to that from the prospective of a labor and employment lawyer and not a plaintiff unversed in discrimination law); see also Brake \& Grossman, supra note 28, at 914 (arguing that while the "rationale for the reasonable belief doctrine is sound . . . [it] has failed to honor its original purpose-to protect the employee whose belief in unlawful discrimination turns out to be mistaken").

41. See, e.g., Booker v. Brown \& Williamson Tobacco Co., 879 F.2d 1304, 1313 (6th Cir. 1989) (holding that participation clause applies when administrative proceedings are instituted leading to the filing of a complaint or charge, including visiting a government agency to inquire about filing a charge); see also Aguilar v. Arthritis Osteoporosis Ctr., No. M-03-243, 2006 WL 2478476, at *6-7 (S.D. Tex. Aug. 25, 2006) (describing different holdings with regard to administrative proceeding in connection with the participation clause). Although legislative history of the anti-retaliation provision is sparse, there is some support in the history for this interpretation. See Interpretative Memorandum of Title VII of H.R. 7152, 110 Cong. Rec. 7212, 7213 (1964) (Retaliation provision "prohibits discrimination by an employer ... against person for opposing 
Participation in an employee's internal investigation into allegations of discrimination conducted apart from a formal charge filed with an administrative agency does not typically fall within the scope of participation clause protection. ${ }^{42}$ Thus, the opposition clause is considered to provide protection during more informal employer or precharge investigations of discrimination. ${ }^{43}$

It is generally recognized that the participation clause, when it applies, affords more complete protection to victims of alleged retaliation than the opposition clause. ${ }^{44}$ One reason for this result is that the clauses are worded differently. ${ }^{45}$ The participation clause protects employees or applicants from discrimination if they have "made a charge, testified, assisted, or participated in any manner in [a Title VII] investigation, proceeding, or hearing. ${ }^{, 46}$ The phrase in any manner has been interpreted literally. ${ }^{47}$ Thus, an employee is protected even if the charge lacks merit or contains allegations that are wrong, defamatory, or malicious. ${ }^{48}$

discriminatory practices, and for bringing charges before the Commission or otherwise participating in proceedings under the title.").

42. See Aguilar, 2006 WL 2478476, at *7; see also Correa v. Mana Products, Inc., $550 \mathrm{~F}$. Supp. 2d 319, 330-31 (S.D.N.Y. 2008) (quoting Bick v. City of N.Y., No. 95 Civ. 8781, 1997 WL 381801 at 329 (S.D.N.Y. July 10, 1997) ("[I]n order to gain protection under the participation clause, the 'participation must be in an investigation or proceeding covered by Title VII, and thus not in an internal employer investigation."')). See generally Long, supra note 2, at 953-54 ("Federal courts uniformly have held that resort to an employer's internal procedures for handling discrimination does not fall under the participation clause for purposes of a retaliation claim ... such activity is protected, if at all, under the opposition clause."); Brake \& Grossman, supra note 28, at 914 (The opposition clause provides protection "where Title VIl's formal enforcement processes have not yet been invoked.").

43. See Title VII of the Civil Rights Act of 1964, 42 U.S.C. $\$ 2000 \mathrm{e}-3$ (a).

44. See Deravin v. Kerik, 335 F.3d 195, 203 \& n.6 (2d Cir. 2003) (noting that the opposition clause is narrower than the participation clause and that courts have held that the participation clause, which protects participation in any manner "is expansive and seemingly contains no limitations); Booker, 879 F.2d at 1312 (recognizing that "federal courts have generally granted less protection for opposition than for participation in enforcement proceedings"); Sias, 588 F.2d at 695 (indicating that the opposition clause offers more limited protection than the participation clause).

45. See Glover v. S.C. Law Enforcement Div., 170 F.3d 411, 415 (4th Cir. 1999) (stating that due to textual differences between the participation and opposition clauses, the participation clause offers broader protection).

46. 42 U.S.C. § 2000e-3(a) (emphasis added); see also Deravin, 335 F.3d at 203; Booker, 879 F.2d at 1312 .

47. See Booker, 879 F.2d at 1312.

48. See Deravin, 335 F.3d at 203-04; Booker, 879 F.2d at 1312 (explaining that protection under the participation clause has been held to exist even if the charge alleges facts that are deemed wrong, malicious, or defamatory); see also Sias, 588 F.2d at 695 (explaining that the participation clause shields an employee from retaliation even if the charge lacks any merit). The participation 
This is not the case with the opposition clause. To determine whether opposition conduct is protected, courts balance the purpose of the act to protect individuals engaging in reasonable opposition activities and Congress' desire not to tie the hands of employers to select and control personnel. ${ }^{49}$ Nonetheless, a wide array of conduct has been considered protected under the opposition clause. ${ }^{50}$ The following discussion focuses on the opposition clause as it concerns the protection Title VII affords employees in the informal, pre-charge workplace setting at issue in Crawford.

\section{B. Crawford: Reading "Oppose" for All It's Worth}

\section{A Broad Reading of Oppose}

During part of an internal investigation of rumors of sexual harassment, Vicky Crawford's employer, Metropolitan Government of Nashville and Davidson County, Tennessee ("Metro") asked her whether she had ever witnessed "inappropriate behavior" by the alleged subject of the investigation, Gene Hughes. ${ }^{51}$ Several employees had complained about Hughes, who himself was the Metropolitan employee typically responsible for investigating discrimination complaints. ${ }^{52}$ Crawford, a 30-year Metro employee, was not among the initial complainants, but the human resources officer investigating the rumors sought her statements as a potential witness because she had worked with Hughes. ${ }^{53}$

clause has also been held to offer broader protection because participation occurs in the context of formal proceedings and thus is "essential to the machinery set up by Title VII." Shoaf v. KimberlyClark Corp., 294 F. Supp. 2d 746, 755-56 (M.D.N.C. 2003).

49. See Booker, 879 F.2d at 1312 (noting that employees are not protected when they violate legitimate employer rules and orders, disrupt the employment environment or interfere with the employer's goals); see also Shoaf, 294 F. Supp. 2d at 754-55 (holding that employee's providing confidential information to another employee who had filed a discrimination claim against their employer was not protected opposition under Title VII, since the employee supplying the information breached the employer's trust and confidence).

50. See, e.g., EEOC v. Navy Fed. Credit Union, 424 F.3d 397, 406 (4th Cir. 2005) (citing Bryant v. Aiken Reg'l Med. Ctrs., Inc., 33 F.3d 536, 543-44 (4th Cir. 2003)) (noting that protected opposition may include staging informal protests, voicing an opinion to an employer about discrimination or voicing complaints about suspected discrimination).

51. See Crawford v. Metro. Gov't of Nashville \& Davidson Cnty., Tenn., 129 S. Ct. 846, 849 (2009).

52. See Crawford v. Metro. Gov't of Nashville \& Davidson Cnty., Tenn., 211 F. App'x 37, 374 (6th Cir. 2006).

53. Crawford, 129 S. Ct. at 849 
Crawford explained in graphic terms that she had not only witnessed Hughes's harassment but had endured it. ${ }^{54}$ Metropolitan took no action against Hughes, but later fired Crawford and two other employees who had also spoken up against Hughes during the investigation. ${ }^{55}$

The lower courts discussed Crawford's claim in the context of Title VII's opposition clause. ${ }^{56}$ Like several other courts that had addressed the matter, the Sixth Circuit previously had held that the participation clause only comes into play in connection with the filing of a charge with the EEOC. ${ }^{57}$ Crawford's case involved pre-charge statements; thus, the Sixth Circuit determined that the participation clause was inapplicable to her retaliation claim. ${ }^{58}$ Moreover, according to Sixth Circuit precedent, protected opposition "demand[ed] active, consistent 'opposing' activities." ${ }^{\text {"9 }}$ The Sixth Circuit held that Crawford's response to questions about Hughes and relaying unfavorable information about him in the process was not the type of rigorous opposition Title VII protected, and her employer was therefore free to fire her. ${ }^{60}$

Reversing, the Supreme Court began its analysis by examining the plain language of Title VII's anti-retaliation provisions, and particularly the term "oppose."61 Consulting dictionaries, the Court explained that oppose carries several meanings, including "to resist or antagonize ... to contend against; to confront; resist; withstand."62 The Court acknowledged that these terms "entail varying expenditures of energy."63 The Court, however, pointed out that the term may also mean "to be hostile or adverse to, as in opinion."

54. Id. Crawford described several run-ins with Hughes. She stated that once Hughes responded to her greeting by "grabbing his crotch and saying '[Y]ou know what's up." Id. She stated that he would repeatedly "put his crotch up to [her] window," and once grabbed her head and lowered it to his crotch. Id.

55. See id.

56. See id. at 850 .

57. Id.; see also Aguilar v. Arthritis Osteoporosis Ctr., No. M-03-243, 2006 WL 2478476, at *6-7 (S.D. Tex. Aug. 25, 2006) (stating that the Fifth, Eighth and Ninth Circuits have held that the participation clause does not apply in the absence of a formal charge filed with the EEOC).

58. See Crawford, $129 \mathrm{~S}$. Ct. at 850 .

59. See id. at 851 .

60. See id.

61. See id. at 850. The Supreme Court did not address the applicability of the participation clause or question the Sixth Circuit's holding about the inapplicability of that clause with respect to pre-charge conduct. See id. at 853 . 1958))

62. See id. at 850 (quoting Webster's NEW INTERNATIONAL DictionaRY 1710 (2d ed.

63. Id.

64. Id. (quoting Random House Dictionary of THE ENGLiSh Language 1359 (2d ed. 
The Court held that Crawford's exposing Hughes's actions qualified as opposition. ${ }^{65}$ For support, it relied on the EEOC's brief, filed in support of the plaintiff. ${ }^{66}$ According to the agency's compliance manual, which the Court essentially adopted, "“[w]hen an employee communicates to her employer a belief that the employer has engaged in ... employment discrimination that communication' virtually always 'constitutes the employee's opposition to the activity.'

The Court explained that while the Sixth Circuit's rule of active, consistent opposing conduct may encompass opposition, it did not reflect the limits of that term. ${ }^{68}$ For instance, the Court noted that one may oppose something, such as capital punishment or slavery by doing nothing more than disclosing one's opposition. ${ }^{69}$ Crawford demonstrates that opposition does not require a plaintiff to launch a letter writing campaign or take to the streets with protest signs. ${ }^{70}$ Considering the breadth of the meaning of the term, including taking no action at all but merely holding a contrary opinion to something, the Court held that a reasonable juror could find that Crawford's statements describing the "louche goings-on" were antagonistic, resistant, or opposition to Hughes's treatment. ${ }^{71}$

1987)).

65. Id. at $850-51$

66. See id. at 851 .

67. Id. at 851 (quoting Brief for the United States as Amicus Curiae Supporting Petitioner at 9, Crawford v. Metro. Gov't of Nashville \& Davidson Cnty., Tenn., 129 S. Ct. 846 (2009) (No. 06 1595) ("When an employee communicates to her employer a belief that the employer has engaged in activity that constitutes a form of employment discrimination, that communication constitutes the employee's opposition to the activity.")). The Court noted that one can imagine exceptions, such as an employee's description of a supervisor's racist joke as hilarious. Id. Such examples were "eccentric," according to the Court. Id. Further, Crawford's case did not fall within the eccentric category. Id.

68. See id. at 851 .

69. Id.

70. Id.; see Thompson v. N. Am. Stainless, LP, 567 F.3d 804, 818 (6th Cir. 2009) (en banc) (Martin, J., dissenting) ("Countless people were known to 'oppose' slavery before Emancipation, or are said to 'oppose' capital punishment today, without writing public letters, taking to the streets, or resisting the government"), cert. granted, 130 S. Ct. 3542 (2010).

71. See Crawford, $129 \mathrm{~S}$. Ct. at 850-51. The Court also rejected arguments advanced by the employer and amici that unless the bar is set high regarding the type of conduct deemed to be opposition, employers would have little incentive to investigate possible discrimination because they will want to avoid the headache of asking about possible discrimination, which could then result in liability as it did here. See id. at 851-52. The Court explained, however, that such reasoning ignores the strong incentive employers have under cases such as Burlington Industries, Inc. v. Ellerth, 524 U.S. 742 (1998), and Faragher v. City of Boca Raton, 524 U.S. 775 (1998). Crawford, 129 S. Ct. at 852 . Under those cases, employers enjoy an affirmative defense to claims 
The Court's decision seems correct considering Title VII's purposes of eliminating discrimination in the workplace, and the Court's recognition that Title VII favors conciliation to litigation. ${ }^{72}$ While Title VII allows certain individuals to sue for discrimination proscribed by the statute (including retaliation), the statute's primary purpose is not to provide redress but to avoid harm to employees by ridding the workplace of discrimination. ${ }^{73}$ Title VII in this sense seeks to avoid litigation where possible in favor of conciliation. ${ }^{74}$ The Court recognized in Crawford that an interpretation of the term "oppose" that promotes an employee's ability to bring discrimination to the attention of an employer without fear of reprisal would best serve that goal. ${ }^{75}$ If an employer asks an employee about discrimination as part of an investigation into alleged discrimination, that employee should be encouraged to speak up without fear of retribution. Allowing the employee to do so would assist the employer's investigation, help to eliminate possible discrimination in the workplace, and possibly avoid litigation. Restricting actionable opposition only to those situations where the employee initiates the conversation about the discrimination with the employer would undermine these goals. The Court's holding, therefore, comports with the statute's primary objective.

\footnotetext{
of hostile work environment committed by a supervisory employee that do not result in a tangible employment action, if the employer exercises reasonable care to prevent and correct promptly any discriminatory conduct, and the plaintiff fails to take advantage of the preventive or corrective opportunities or to avoid harm otherwise. See id. Accordingly, the Court reasoned that wherever the bar is set with regard to retaliation claims, employers have a strong incentive (in the form of the affirmative defense) to ferret out and put a stop to discriminatory activity in their operations. Id. Further, the Court explained that the Sixth Circuit's rule would create an untenable catch 22 for employees. See id. at 852-53. If the employee speaks up in response to an employer's inquiry during an internal investigation, the employer would be free to sanction the employee without penalty. Id. If, however, that employee keeps quiet and later files a Title VIl claim, the employer may escape liability under Burlington Industries and Ellerth by arguing that while it took reasonable care to prevent and correct discrimination, the employee failed to take advantage of the opportunities the employer provided during the investigation. Id.

72. See Pa. State Police v. Suders, 542 U.S. 129, 145 (2004) (discussing Congress' purpose of promoting conciliation rather than litigation in Title VII controversies); see, e.g., McKennon v. Nashville Banner Pub'g Co., 513 U.S. 352, 358 (1995).

73. See Faragher, 524 U.S. at 806 ("It would therefore implement clear statutory policy and complement the Government's Title VII enforcement efforts to recognize the employer's affirmative obligation to prevent violations....").

74. See Suders, 542 U.S. at 145 (2004). ("The Court reasoned that tying the liability standard to an employer's effort to install effective grievance procedures would advance Congress' purpose 'to promote conciliation rather than litigation' of Title VII controversies." (citing Burlington Industries, Inc., 524 U.S. at 764))

75. See Crawford, $129 \mathrm{~S}$. Ct. at 852.
} 
As explained below, however, Justice Alito opined that the court went too far by noting that the term oppose could mean opposition by opinion. ${ }^{76}$ That definition, he warned, could "open the door" to silent opposition. ${ }^{77}$ That concern prompted Justice Alito to set the threshold for actionable opposition at active, purposive conduct. ${ }^{78}$

\section{The Concurrence: A Step too Far in His "Opinion"}

Justice Alito joined by Justice Thomas concurred in the Court's judgment. ${ }^{79}$ He took the majority to task, however, for its "dicta" that the term "oppose" may mean "to be hostile or adverse to, as in opinion." ${ }^{, 80}$ According to Justice Alito, this definition potentially "embraces silent opposition." 81 Justice Alito proposed limiting opposition to active, purposive conduct. To that end, he agreed with the definition of "oppose" that the plaintiff in Crawford suggested, which included "taking action (including making a statement) to end, prevent, redress, or correct unlawful discrimination. ${ }^{, 82}$ This standard necessarily includes specifically intending to bring a grievance to an employer's attention so that it may take one of the enumerated actions. ${ }^{83}$

Justice Alito admitted that "to be hostile or adverse to, as in opinion" was an accepted usage of the term "oppose," but he questioned whether such opposition was covered by Title VII. ${ }^{84} \mathrm{He}$ warned that "[i]t would open the door to retaliation claims by employees who never expressed a word of opposition to their employers." $" 85$ He acknowledged many such claims would fail because the employee would be unable to

76. See id. at 854 (Alito, J., concurring) ("While [defining 'oppose' as 'hostile or adverse to, as in opinion'] is certainly an accepted usage of the term 'oppose,' the term is not always used in this sense, and it is questionable whether silent opposition is covered by the opposition clause of 42 U.S.C. 2000e-39a.").

77. Id.

78. See id.

79. Id. at 853

80. See id. at 854. Justice Alito agreed with the Court's holding that Crawford's testimony given during an internal investigation satisfied the definition of opposition conduct. Id. at 853 . He further agreed with the EEOC's position that an employee communicating a belief about discrimination is virtually always opposition. See id.

81. Id. at 854 .

82. Id.

83. Id. Justice Alito opined that a lesser standard that protects conduct that "is not active and purposive" would "have important practical implications." Id.

84. See id.

85. Id. 
show the employer knew of the opposition, and thus would be unable to prove a causal connection between the opposition and the retaliatory act that allegedly resulted from that opposition. ${ }^{86}$ He noted exceptions, however, where the employee could raise an issue of fact on the question of causation. ${ }^{87}$ This might occur, for instance, where the employee alleges he complained of discrimination to a coworker "at the proverbial water cooler" or "in a workplace telephone conversation that was overheard by a co-worker," or "at a restaurant or tavern frequented by co-workers" or while attending "a neighborhood picnic attended by a friend or relative of a supervisor"- the inference being that the employee's opposition conduct somehow made it back to the plaintiff's employer. ${ }^{88}$

Justice Alito's "active, purposive" requirement is cramped. For instance, in Crawford the court used as an example of opposition conduct of a supervisor who refuses to discharge a subordinate although the supervisor is directed to do so for discriminatory reasons. ${ }^{89}$ Such conduct has been called passive in contrast to active opposition. ${ }^{90}$ Crawford would appear to protect the supervisor in these circumstances. ${ }^{9 !}$

Assuming Justice Alito's definition would embrace passive opposition, his purposive requirement seems out of step with Crawford and the plain language of Title VII. The majority in Crawford pointed out that people opposed slavery without doing any more than disclosing that opposition. ${ }^{92}$ Such persons may have expressed their opposition without doing so to end, prevent, or correct it but simply as a means to communicate their feeling about it or indeed for no particular reason at all. $^{93}$ Further, the statute imposes no intent requirement on the

86. See id. at 854 .

87. See id.

88. Id.

89. See id. at 851 (majority opinion) ("[W]e would call it 'opposition' if an employee took a stand against an employer's discriminatory practices not by 'instigating' action, but by standing pat, say, by refusing to follow a supervisor's order to fire a junior worker for discriminatory reasons.").

90. See McDonnell v. Cisneros, 84 F.3d 256, 262 (7th Cir. 1996) (holding that opposition may encompass such "passive" conduct as refusing to carry out an employer's wish to prevent subordinates from filing discrimination complaints); see also discussion infra Part III.A.

91. See McDonnell, 84 F.3d at 262; cf. EEOC v. Navy Fed. Credit Union, 424 F.3d 397, 407 (4th Cir. 2005) (supervisor opposed employer's scheme to fire her subordinate who had complained about discrimination by refusing to go along with the employer's plan to give the subordinate favorable but inaccurate evaluations to combat the subordinate's charges of retaliation).

92. Crawford, $129 \mathrm{~S}$. Ct. at 851 .

93. See id. at 851 . 
employee. ${ }^{94}$ It says nothing about the employee having to bring the opposition directly to the employer's attention. ${ }^{95}$ The intent requirement falls on the employer, which may not intentionally discriminate against the employee because of the employee's opposition. ${ }^{96}$

Yet, Justice Alito's concern about silent or unexpressed opposition is not totally unfounded. Because Title VII liability requires a showing that the employer discriminated against the employee because of the employee's opposition, the employee must prove the employer was aware of it. $^{97}$ Courts, however, have been parsimonious with the knowledge requirement. Unless a plaintiff can show by direct or circumstantial evidence that the employer knew of the protected activity, the employee's claim will most likely fail. ${ }^{98}$ Speculation about

94. See Title VII of the Civil Rights Act of 1964, 42 U.S.C. $§ 2000 \mathrm{e}-3$ (a) (2006).

95. See id.

96. See id.

97. See id.

98. Courts have not hesitated to rule against plaintiffs where they present facts similar to those presented by Justice Alito in his concurrence where there is no evidence the employer or the decision maker actually learned of the protected activity. See discussion supra p. 117; see, e.g., Thompson v. N. Am. Stainless, LP, 567 F.3d 804, 809 (6th Cir. 2008) (while plaintiff alleged that coworkers were aware of his fiancée's assistance with his EEOC charge, plaintiff failed to allege his employers knew), cert. granted, 130 S. Ct. 3542 (2010); Ramirez v. Gonzalez, 225 F. App'x 203, 209-10 (5th Cir. 2007) (judgment in favor of employer properly granted where plaintiff conceded she did not know whether person who made the decision to terminate her had learned of her complaints regarding alleged discrimination); Webb v. Level 3 Commc'ns, LLC, 167 F. App'x 725, 735 (10th Cir. 2006) (temporal proximity may be sufficient to establish a causal connection between the protected activity and the adverse action, but proof is still required that decision maker knew of protected activity); McShane v. U.S. Att'y Gen., 144 F. App'x 779, 790-91 (11th Cir. 2005) (while close temporal proximity between the protected activity and adverse action may show the two are related, neither a court nor a jury may impute knowledge of protected activity where the employer has sworn that he had no actual knowledge of it); Edwards v. Hyundai Motor Mfg. Ala., LLC, No. 2:07CV908 (MHT), 2009 WL 1257164, at *2 (M.D. Ala. May 5, 2009) (rejecting retaliation claim where employee complained about sexual harassment but presented no evidence that such complaint reached her supervisor or anyone else who may have retaliated against her); see also Demers v. Adams Homes of Nw. Fla., Inc., 321 F. App'x 847 (11th Cir. 2009) ("Even after Crawford, to engage in protected activity, the employee must still, 'at the very least, communicate her belief that discrimination is occurring to the employer . . . "') (quoting Webb $v$. R\&B Holding Co., Inc., 992 F. Supp. 1382, 1390 (S.D. Fla. 1998)); Mickey v. Zeidler Tool \& Die Co., 516 F.3d 516,525 (6th Cir. 2008) (explaining that in some situations "where an employer fires an employee immediately after learning of a protected activity, we can infer a causal connection between the two actions" even if there is no other evidence of retaliation (emphasis added)); Tomanovich v. City of Indianapolis, 457 F.3d 656, 669 (7th Cir. 2006) (employee's retaliation claim failed as he failed to show employer knew of his protected activity); Seay v. Tenn. Valley Auth., 340 F. Supp. 832, 841 (E.D. Tenn. 2004) (Title VII liability depends on decision maker having actual knowledge of employee's protected activity.); EEOC v. Carolina Freight Carriers Corp., 723 F. Supp. 734, 748 (S.D. Fla. 1989) ("Actual knowledge is required to raise the inquiry that the adverse employment 
knowledge of protected activity generally does not suffice. Thus, Justice Alito's concerns about the dangers of silent opposition becoming viable may be overstated.

Still, might Crawford crack open the door to silent opposition? Some have opined on the possibility. ${ }^{99}$ The following section addresses this question. It explains why silent opposition is inconsistent with the statute's language, scheme, and purposes. ${ }^{100}$

\section{SILENT OPPOSITION: A TITLE VII NONSTARTER}

Whether the term "has opposed" takes on the meaning of "opinion" depends on canons of statutory interpretation. When a statutory term is undefined, the Court has directed that the term is to take on its everyday common dictionary meaning. ${ }^{101}$ An undefined statutory term may have multiple meanings (as does the term "oppose"), but whether it takes on any and all of those meanings is another matter. ${ }^{102}$ For instance, "[a] word in a statute may or may not extend to the outer limits of its definitional possibilities." everyday meaning, for purposes of Title VII might encompass opinion or require opposition in its more expressive forms. ${ }^{104}$

In Robinson v. Shell Oil Co. ${ }^{105}$ the Court set forth the paradigm to examine whether statutory language is so plain that it can only mean one

action and the employee's [protected] activities were causally linked."). But see Sharp v. City of Houston, 164 F.3d 923, 930-31 (5th Cir. 1999) (holding that in addition to possessing actual knowledge, an employer may also be liable if it had constructive notice of harassment if the harassment was so "open and pervasive that the employer should have known of it, had it but opened its corporate eyes").

99. See, e.g., Lough, supra note 7, at 10 (explaining that Crawford defined opposition to be adverse to as in opinion and may set the stage for silent opposition); see also Thompson, 567 F.3d at 818 (Martin, J., dissenting) (relying on Crawford to demonstrate that the term "oppose" includes "silent opposition of everything from gay marriage to the death penalty, without requiring anyone to shout it from the rooftops"); AVERY, ONTIVEROS, CORRADA, SELMI \& HART, supra note 7, at 173 (noting that Crawford "seems to suggest that silent opposition to unlawful discrimination can sometimes be protected").

100. By silent opposition, this article refers to unexpressed opinion. This definition of silent opposition is reasonable in light of Crawford's explanation that opposition may mean "to be hostile or adverse to, as in opinion." See Crawford v. Metro. Gov't of Nashville \& Davidson Cnty., Tenn., 129 S. Ct. 846, 849 (2009)

101. See id. at 850 .

102. Dolan v. U.S. Postal Serv., 546 U.S. 481, 486 (2006).

103. Id.

104. See id.

105. 519 U.S. 337 (1997). 
thing or ambiguous such that other meanings are possible. ${ }^{106}$ This paradigm requires examining (1) the specific statutory language itself, (2) the context in which the language is used, and (3) the broader context of the statute as a whole to determine whether the language at issue has a plain and unambiguous meaning with regard to the particular dispute in the case. ${ }^{107}$ In determining the meaning of a statutory term it is also proper to consider relevant judicial and other authority on the issue. ${ }^{108}$ Once the statutory term is considered ambiguous, however, Robinson instructs that the meaning attributed to the term should be the one most consistent with the statute's purposes. ${ }^{109}$ The following discussion

106. See id. at 340; see also EEOC v. Total Sys. Servs., Inc., 240 F.3d 899, 901 (11 th Cir. 2001) (Barkett, J., dissenting) (a statutory term is ambiguous when it is susceptible of multiple interpretations).

107. See Robinson, 519 U.S. at 340-41. In Robinson, the Court determined whether Title VIl's anti-retaliation provision protected former as well as current employees. See id. at 339 . The statute's language expressly proscribes retaliation against "employees or applicants for employment." See id. (citing 42 U.S.C. $\$ 2000 \mathrm{e}-3$ (a) (1964)). The Court explained that whether the statute was ambiguous as to whether it excluded "former employees" had to be determined by not only the term "employee" but how that term is used and the broader context of the statute as a whole. See id. at 341 . The Court further adopted the meaning that comported with the purposes of the statute. See id.; see also Total Sys. Servs., Inc., 240 F.3d at 899-902 (Barkett, J., dissenting) (applying the analysis in Robinson to determine whether the participation clause applies in connection with an employer's internal investigation).

108. See Dolan, 546 U.S. at 486 (interpreting a word or phrase in a statue depends on reading the entire statutory text, considering the purposes and context of the statute and "any precedents or authorities that inform the analysis"). The Court's analysis in Dolan is similar to the analysis in Robinson, and indeed the Dolan discussion may be more on point. There, the Court determined whether the statutory term "negligent transmission of letters or postal matter" contained in the Federal Torts Claim Act meant mail that is negligently left on a porch resulting in a slip and fall. See id. at 485 . The Court acknowledged that the term negligent transmission "could embrace a wide range of negligent acts ... including creation of slip-and-fall hazards from leaving packets and parcels on the porch of a residence." $I d$. at 486 . The Court noted that the dictionary definition of "transmission" implies completed delivery of it. See id. (stating that "in ordinary meaning and usage, transmission of the mail is not complete until it arrives at the destination"). This was inferred from Webster's Third New International Dictionary defining transmission as "an act, process, or instance of transmitting" and defining transmit as "to cause to go or be conveyed to another person or place"). Id. (quoting WEBSTER's THIRD NEW INTERNATIONAL DicTIONARY 2429 (1971)). The Court, however, determined that the meaning of negligent transmission of the mail could not be determined in isolation, and after considering other factors, such as the entire statutory text, purposes of the statute and relevant precedent, it thought a narrower reading of the term was appropriate. See id. (holding that negligent transmission for purposes of the statute "does not go beyond negligence causing mail to be lost or to arrive late, in damaged condition, or at the wrong address").

109. See Robinson, 519 U.S. at 340-41; Total Sys. Servs., Inc., 240 F.3d at 900 (applying Robinson, where courts are required to "resolve the case in favor of the reading that best helps to realize the goals of the statute" when looking to the broader context of the statute to resolve an ambiguity). 
examines these areas and determines that collectively they show the term "opposed" plainly does not contemplate silent opposition.

\section{A. Unpacking "Has Opposed"}

Crawford shows the term "oppose" in Title VII may be ambiguous, i.e., the word might potentially have more than one meaning in the context of the statute. ${ }^{110}$ Crawford not only rejected the Sixth Circuit's cramped definition of the undefined term "oppose" contained in Title VII, but also explained that the word could mean any number of things, including being "hostile or adverse to, as in opinion." "11 Justice Alito acknowledged in his concurring opinion that this was an accepted meaning of the term. ${ }^{112}$ Justice Alito's concurrence makes clear, the term "oppose" is not only undefined but ambiguous. ${ }^{113}$

Still, the Court's discussion of retaliation generally, as well as the interpretation of the term "has opposed" under Title VII by the lower courts, suggests it contemplates more than opinion. ${ }^{114}$ Reading the provision as requiring some form of expression versus merely holding an opinion is consistent with the Supreme Court's characterization of a retaliation claim under Title VII as a conduct-based claim. In Burlington Northern \& Santa Fe Railroad Co. v. White, ${ }^{115}$ the Court explained that

110. See Crawford v. Metro. Gov't of Nashville \& Davidson Cnty., Tenn., 129 S. Ct. 846, 850 (2009).

111. See id. at 850-51.

112. See id. at 854 (Alito, J., concurring).

113. Id. See Thompson v. N. Am. Stainless, LP, 567 F.3d 804, 819 (6th Cir. 2009) (en banc) (Martin, J., dissenting) (stating that Justice Alito's concurrence demonstrates 'the meaning of 'oppose' is not plain"), cert. granted, $130 \mathrm{~S}$. Ct. 3542 (2010). Title VII uses the term "has opposed." Id. The term is therefore used in its present perfect tense. See GERALDINE WOODS, ENGLISH GRAMMAR FOR DUMMIES 34-35 (2d ed. 2010). That tense suggests that some action or condition began in the past and continues into the present. See id. The present perfect tense indicates that Congress intended that the employee or applicant began opposing the challenged unlawful employment practice at some point in the past-presumably after the unlawful employment practice occurred-and that the opposition may continue into the present. See id. The tense is consistent with both conduct, such as "the boy has eaten the grapes," as well as a condition or state of being, such as "she has loved him a long time." See id. The tense does not necessarily preclude opposition by opinion and hence silence. Certainly, one could have began opposing an unlawful employment practice as in opinion at some point in the past, presumably after the unlawful employment practice began, and that adverse opinion could continue into the present and future. The fact that the term is used in its present perfect tense does not affect the analysis.

114. See Crawford, $129 \mathrm{~S}$. Ct. at 854 (discussing the practical implications in interpreting the opposition clause to protect conduct that is not active and purposive).

115. 548 U.S. 53 (2006). 
unlike the substantive provisions of the statute, which protect individuals because of who they are, i.e., their status, the anti-retaliation provision "seeks to prevent harm to individuals based on what they do, i.e., their conduct." 116 Subsequent decisions have reaffirmed that a potential claim of retaliation under the opposition clause is triggered when an employee communicates opposition to an employer's alleged unlawful employment practice and is sanctioned as a result of that communication. ${ }^{117}$ Accordingly, while the Court in Crawford

116. Id. at 63; DeCaire v. Mukasey, 530 F.3d 1, 19 (1 st Cir. 2008) (holding that the district court erred when it decided against plaintiff on her retaliation claim on the basis that had she been a male, the employer would have retaliated in the same manner; a retaliation claim does not hinge on whether plaintiff is a particular gender, but on whether she engaged in protected activity and was discriminated against as a result). The provision traditionally has been interpreted by the courts to protect conduct. See, e.g., Payne v. McLemore's Wholesale \& Retail Stores, 654 F.2d 1130, 1136 (5th Cir. 1981) (noting that Title VII's anti-retaliation provision "requires conduct by the plaintiff that is in opposition to an unlawful employment practice of the defendant").

117. In Gomez-Perez v. Potter, 128 S. Ct. 1931, 1943 (2008), and CBOCS West, Inc. v. Humphries, $128 \mathrm{~S}$. Ct. 1951 (2008), the Court appeared to retreat from its characterization of retaliation as a conduct-based claim and that such a claim is conceptually distinct from a statusbased claim. See, e.g., Gomez-Perez, 128 S. Ct. at 1937 n.1; CBOCS West, 128 S. Ct. at 1960-61. A careful reading of these cases demonstrates that this is not true. These decisions do not alter the conduct-based nature of the retaliation claim because it is the complainant's conduct that triggers the cause of action. In Gomez-Perez and CBOCS West, the Court held that a broad proscription of discrimination on the basis of a protected characteristic (e.g., age or race) encompasses a proscription on retaliation as well. For instance, in Gomez-Perez, the Court held that the federal sector provisions of the ADEA, which bars discrimination "based on age" encompasses a claim for retaliation as well. See $128 \mathrm{~S}$. Ct. at 1943 . The Court relied heavily on principles of stare decisis in doing so and particularly in Jackson v. Birmingham Bd. of Educ., 544 U.S. 167 (2005). There, the Court held that Title IX, which bars recipients of federal funds from discriminating on the basis of sex, encompassed an implied right of retaliation. According to the Court, discrimination because the person has complained about sex discrimination is merely another form of discrimination on the basis of sex. See id. at 173-74. Accordingly, a statute that bars discrimination on the basis of sex also bars discrimination because of a complaint about sex discrimination. See id. The Court applied a similar rationale in CBOCS West and Gomez-Perez. What is clear, however, is that in each case the conduct of the complainant triggered the retaliation claim. It is only when the employee complains about the discrimination, i.e., engages in some expressive act pertaining to the discrimination, and the employer discriminates on that basis (i.e., on the basis of the complaint), is retaliation relevant. This understanding of how these claims work is evident from the Court's discussion in these cases. See CBOCS West, $128 \mathrm{~S}$. Ct. at 1954 (holding that retaliation claim arises under section 1981 when a person complains about a violation of another person's contract-related right); Gomez-Perez, $128 \mathrm{~S}$. Ct. at 1935 (holding that retaliation claim arises under federal-sector provision of the ADEA when a person is discriminated against for filing a complaint of age discrimination); Jackson, 544 U.S. at 174 (holding that retaliation claim arose because the plaintiff complained about sex discrimination against his students). Thus, even after Gomez-Perez and $C B O C S$ West, a claim of retaliation retains its conduct-based nature. As these cases make clear, the cause of action arises when an individual is retaliated against for complaining about (or engaging in some form of expression concerning) the underlying discrimination. 
acknowledged that "to be hostile or adverse to, as in opinion" was a meaning of opposition, it did not suggest that merely holding an opinion without more would satisfy the statutory requirement of opposition activity. ${ }^{118}$ Rather, it adopted the EEOC's interpretation of the term, suggesting that the opposition to an unlawful practice exists from its disclosure. $^{119}$ This disclosure suggests some expression or communication of opposition beyond mere opinion.

The Court suggested in Crawford that opposition may be inferred from the circumstances. ${ }^{120}$ The discussion also shows more than opinion is necessary. ${ }^{121}$ For instance, in McDonnell v. Cisneros, ${ }^{122}$ a case cited approvingly in Crawford, ${ }^{123}$ the Seventh Circuit held that a male employee had stated a claim of retaliation when he was fired for refusing to control his subordinate by urging her to drop her complaints of sexual harassment. ${ }^{124}$ The Seventh Circuit acknowledged that this form of opposition was passive as it consisted of failing to obey an order to prevent a subordinate from complaining of discrimination. ${ }^{125}$ According to the court, however, passive resistance is a time-honored form of opposition. ${ }^{126}$ Although the conduct in McDonnell was described as passive, it cannot properly be characterized as merely opinion or silent opposition. ${ }^{127}$ Rather, it expressed opposition, manifested by a refusal to participate in an employer's discriminatory activity.

The Ninth Circuit more directly addressed passive resistance as a form of expressive opposition in Thomas v. City of Beaverton. ${ }^{128}$ In that case, the plaintiff, Annette Thomas, prevailed in a retaliation action under the First Amendment and Title VII after refusing to pass over one of her subordinates, Susie Perry, for a promotion because of Perry's prior discrimination lawsuit against their employer. ${ }^{129}$ In response to concerns from Thomas's supervisor about hiring Perry because of

118. See Crawford, 129 S. Ct. at 850-51

119. See id. at 851 .

120. See id. at 850 .

121. See id.

122. 84 F.3d 256 (7th Cir. 1996).

123. See Crawford, $129 \mathrm{~S}$. Ct. at 851 (noting that opposition may occur by disobeying management orders to prevent a subordinate from filing an EEOC charge).

124. See McDonnell, 84 F.3d at 261-62.

125. See id. at 262.

126. See id.

127. See id.

128. 379 F.3d 802 (9th Cir. 2004).

129. See id. at 805 . 
Perry's prior lawsuit, Thomas responded that she could not justify refusing to hire Perry because she was the most qualified candidate. ${ }^{130}$ After Perry received the promotion, Thomas's supervisor retaliated against Thomas in numerous ways. ${ }^{131}$ Thomas subsequently sued under the First Amendment and Title VII contending that she was fired because her superior believed she was opposing discrimination by promoting Perry despite the employer's disapproval of the promotion due to Perry's prior complaints of discrimination and retaliation. ${ }^{132}$

In determining whether Thomas's conduct was expressive conduct under the First Amendment, the court asked whether Thomas intended "to convey a particularized message . . . [and whether] in the surrounding circumstances the likelihood was great that the message would be understood by those who viewed it." 133 The court held that by, among other things, telling her superiors that she "could not justify" not giving Perry the promotion, a fact finder could reasonably infer that Thomas's refusal to acquiesce to her superior's treatment of Perry was intended to convey her disapproval of the unlawful retaliation against Perry. ${ }^{134}$ Further, the court found that the likelihood was great that an audience would understand Thomas's conduct to convey a message of disapproval of the retaliation against Perry. ${ }^{135}$ The court relied on these same facts to reverse summary judgment on Thomas's Title VII retaliation claim. ${ }^{136}$ According to the court, based on Thomas's actions, there was sufficient evidence to infer that Thomas had opposed retaliation against Perry because of Perry's prior Title VII suit. ${ }^{137}$

130. See id. at 806 .

131. See id. at 807 . Thomas was placed on an extended probation and after her supervisor complained of her job performance-complaints which had not been raised prior to Perry's promotion-Thomas was fired. See id.

132. See id. at $807-08$.

133. Id. at 810 (quoting Spence v. Washington, 418 U.S. $405,410-11$ (1974)).

134. See id.

135. See id.

136. Id. at 812 .

137. See id. While First Amendment cases such as in Thomas are helpful to the present discussion to demonstrate when opposition might be expressive, such cases are not on all fours with the standard proposed here. This is so because as explained later, an employer may reasonably infer opposition from a plaintiff's expression although the plaintiff does not intend to express opposition. See discussion infra Part IV.B. Under the First Amendment, a person must engage in conduct with the purpose of demonstrating a particularized message and the likelihood must be "great that the message would be understood by those who viewed it." See Spence, 418 U.S. at 410-11. Under the standard set forth in this article, where the employee's expression reasonably manifests opposition, regardless of the employee's intention, and the employer discriminates on the basis of that manifestation, nothing else is required to impose liability. See Title VII of the Civil Rights Act of 
Cases such as Cisneros and Thomas demonstrate that action or inaction often speak as loudly as words. Whether characterized as passive resistance or a refusal to act, the opposition in such cases goes beyond merely holding an opinion to doing something or refraining from doing it in a manner from which a reasonable inference of opposition to an alleged unlawful employment practice may be inferred. As explained, Crawford, which discussed opposition in its various forms, opens the door to opposition by passive resistance. ${ }^{138}$ The resistance expresses opposition.

The ambiguity or plainness of the term oppose, however, cannot be determined in isolation. The analysis turns to the context in which the language is used by examining the anti-retaliation provision as a whole and then the structure and purposes of Title VII to ascertain whether the term is ambiguous as to whether it contemplates silent opposition.

\section{B. Silent Opposition is Inconsistent with Title VII's Anti-Retaliation Provision}

Title VII's anti-retaliation provision involves three concepts relevant to the present discussion, none of which are consistent with silent opposition: (1) motivation, (2) knowledge, and (3) instances where the victim of discrimination involves a third party in his or her opposition activity.

\section{Motivation}

The anti-retaliation provision contains an explicit element of causation. ${ }^{139}$ The provision bars an employer from discriminating

1964, 42 U.S.C. $\S 2000 \mathrm{e}-3$ (a) (2006). This interpretation of the statute is consistent with the statute's language, which bars the employer from retaliating against an employee because of the employee's opposition. Id. The statute says nothing of the employee's intent. Id.

138. See Crawford v. Metro. Gov't of Nashville \& Davidson Cnty., Tenn., 129 S. Ct. 846, 851 (2009).

139. See 42 U.S.C. $\S 2000 \mathrm{e}-3(\mathrm{a})$. Rarely do employers announce their intention to discriminate; thus, courts have allowed plaintiffs to show causation either by direct or circumstantial evidence. See, e.g., Dixon v. Gonzales, 481 F.3d 324, 333 (6th Cir. 2007). Most employees attempt to prove retaliation using the familiar McDonnell Douglas burden shifting scheme. See id. To state a claim under this standard, a plaintiff must show he or she (1) engaged in protected activity; (2) suffered an adverse employment action; and (3) causation. See id. If the plaintiff successfully makes this showing, the defendant must "articulate [a] legitimate, nondiscriminatory reason" for the alleged adverse action taken against the plaintiff. See id. (quoting McDonnell Douglas Corp. v. Green, 411 U.S. 792, 802 (1973)). Assuming the employer meets this burden, the 
because the employee has opposed an unlawful employment practice under Title VII. ${ }^{140}$ Where the opposition does not serve as the motivation for or cause of the retaliation, the employer is not liable. ${ }^{141}$

\section{Knowledge}

Because a plaintiff must show that the adverse action resulted from the employee's engagement in protected activity, the anti-retaliation provision contains an implicit knowledge component as well. ${ }^{142}$ These concepts are intertwined. Unless the plaintiff can show that the employer knew of the protected activity, it is speculative at best to suggest the employer acted because of that protected activity. ${ }^{143}$ For this reason, courts typically hold that an employer must have actual knowledge of the protected activity. ${ }^{144}$ If knowledge of opposition is a necessary component of a retaliation claim, and it is certainly is as it is a precursor to motivation, then circumstances must exist that would put the employer on notice of the employee's opposition activity, beyond the employee holding an opinion. ${ }^{145}$

\section{Opposition for and on Behalf of a Victim of Discrimination}

Title VII allows a victim of discrimination to oppose that discrimination through a representative. ${ }^{146}$ Thus, a victim of alleged

plaintiff must show that the reason advanced by the defendant was pretext for discrimination. See Dixon, 481 F.3d at 333. Thus, causation is an element of the plaintiff's prima facie case. See id.

140. See 42 U.S.C. $\S 2000 \mathrm{e}-3(\mathrm{a})$.

141. See Greenlee v. Sw. Health Systems, Inc., No. 06-cv-00103-EWN-KLM, 2007 WL 2320544, at*12 (D. Colo. Aug. 10, 2007).

142. See id. at *11 ("Obviously, where the person who takes adverse action against a plaintiff was unaware of the plaintiff's protected conduct, causation is lacking.").

143. See id. at 12.

144. See supra note 98 and accompanying text.

145. While motivation and knowledge are intertwined, I do not suggest that the employer's knowledge is the sine qua non of its motivation. Liability under Title VII is driven by motivation, not knowledge. See 42 U.S.C. $\S 2000 \mathrm{e}-3$ (a). Where, however, the plaintiff shows that the employer was motivated to retaliate because of the protected activity, knowledge is also present. But the opposite is not always true. A plaintiff can prove knowledge of protected activity on the employer's part, but fail to show the employer was motivated to discriminate because of the protected activity despite knowledge of it. See Greenlee, 2007 WL 2320544, at *12 (explaining that mere knowledge of the protected activity is insufficient to prove retaliation; plaintiff must present evidence from which a reasonable inference may arise that the employer's motive to discriminate was based on the protected activity of which the employer is aware).

146. See EEOC v. V \& J Foods, Inc., 507 F.3d 575, 580 (7th Cir. 2007). 
discrimination may affirmatively request another individual, e.g., a lawyer or other representative, to complain to the employer on the victim's behalf. ${ }^{147}$ Most but not all courts would protect the victim in such circumstances. ${ }^{148}$

A victim of alleged discrimination may complain about alleged discrimination to a third party, but with no expectation that the complaint will be relayed to the employee's employer. ${ }^{149}$ Whether the victim is protected if a complaint is passed to the employer without a specific request from the victim to do so is still unsettled in the lower courts. ${ }^{150}$ The hesitancy to recognize such claims relates to Justice Alito's concern about silent opposition and is therefore relevant to the present discussion.

\section{a. Purposive Opposition}

Most courts appear to allow employer liability under the antiretaliation provision when the individual discriminated against engages in protected activity by asking a third party to complain on the individual's behalf. $^{151}$ The statute proscribes retaliation against an

147. See id.

148. See id. at 581 .

149. See, e.g., Pitrolo v. Cnty. of Buncombe, N.C., No. 07-2145, 2009 WL 1010634, at *3 (4th Cir. Mar. 11, 2009) (holding that plaintiff's statements to her father of discrimination at the workplace was not protected activity because there was no evidence that the plaintiff intended for her father to pass along her complaints to her employer).

150. See $V \& J$ Foods, 507 F.3d at 581 .

151. See EEOC v. Ohio Edison Co., 7 F.3d 541, 543, 545-46 (6th Cir. 1993) (holding that plaintiff stated a claim for retaliation after his offer for reinstatement was revoked after his representative engaged in protected activity on his behalf); see also Holt v. JTM Indus., Inc., 89 F.3d 1224, 1227 n.2 (5th Cir. 1996) (citing Ohio Edison approvingly for the proposition that one who engages an agent to complain about discrimination on his or her behalf falls within the scope of the anti-retaliation provision as that person has opposed an unlawful employment practice under the statute's plain language); cf. Ackel v. Nat'l Commc'ns, Inc., 339 F.3d 376, 385 (5th Cir. 2003) (holding that plaintiff had not engaged in protected activity when she was fired after complaining of discrimination to a coworker, who in tum informed the company's general manager and president; plaintiff neither complained on her own nor asked her coworker to act on her behalf). In $V \& J$ Foods, 507 F.3d at 580-81, a pre-Crawford case, the Seventh Circuit opined that it did not need to hold that every time an alleged victim of discrimination uses a representative to complain on his her behalf, the victim is protected. Id. However, the Court extended protection to particular types of agents-lawyers and parents for minor children. Id. at 580. Thus, in $V \& J$ Foods, the court held that a teenage daughter was protected against retaliation where her mother complained on her daughter's behalf. See id. at 580-81 (minor daughter asserted viable retaliation claim against employer when the child's mother opposed discrimination on behalf of her teenage daughter; where a parent, guardian, or lawyer acts on behalf of another, the opposition is imputed to the underlying 
employee because "he" has opposed an unlawful employment practice. ${ }^{152}$ The third party who actually complains to the employer is deemed to act as the representative or agent of the victim. ${ }^{153}$ Consequently, the "he" in the statute is broad enough to cover the victim who complains through an agent. ${ }^{154}$

The courts that have directly addressed the issue have had little problem recognizing a retaliation claim on behalf of the underlying victim in this situation. ${ }^{155}$ The victim who asks another to complain on his or her behalf acts purposively, although indirectly, as he or she seeks to bring a grievance to the employer's attention presumably to end, correct, or remediate it or for some other reason. The underlying victim's opposition conduct should satisfy the stringent active, purposive standard proposed by Justice Alito.

\section{b. Non-Purposive Opposition}

A different situation arises, however, where the underlying victim complains to a third party who, in turn, passes the information on to the employer without a specific request by the victim to do so. Lower courts have been hesitant to extend protection to the victim who failed to ask purposively. For instance, the Fourth Circuit in Pitrolo v. County of Buncombe $^{156}$ held that an employee's complaint about sex discrimination made to her father, who reported the complaint to her employer, was not actionable. ${ }^{157}$ The Court held that there was no evidence that the plaintiff intended for her father to pass along her complaint although it was undisputed that her employer actually learned of her complaint. ${ }^{158}$ In so holding, the court pointed to Justice Alito's concurrence to demonstrate that "Crawford does not extend to cases where employees do not communicate their views to their employers through purposive conduct."

\footnotetext{
victim of discrimination). While the court approved representative opposition through a parent/guardian or lawyer, the court did not reach the issue of whether opposition manifested by another type of representative is actionable. See id. at 581 .

152. See Title VII of the Civil Rights Act of 1964,42 U.S.C. $§ 2000 \mathrm{e}-3$ (a) (2006)

153. See Ohio Edison Co., 7 F.3d at 545-46.

154. See id.

155. See id.

156. No. 07-2145, 2009 WL 1010634 (4th Cir. Mar. 11, 2009).

157. See id. at $* 3$.

158. See id.

159. See id. at *3 n.6.
} 
Similarly in Ackel v. National Communications, ${ }^{160}$ a plaintiff told a non-supervisory employee that a company vice-president made frequent sexual advances toward her. ${ }^{161}$ The plaintiff's coworker reported the charge to her employer, and the plaintiff was subsequently discharged. ${ }^{162}$ The Fifth Circuit rejected the plaintiff's retaliation claim as she neither complained directly to management herself about the harassment nor directed her coworker to complain on her behalf. ${ }^{163}$ Her coworker was acting solely on her own accord. ${ }^{164}$

Refusing protection in cases such as Pitrolo and Ackel may be a precaution to prevent protecting silent opposition. That concern, in part, animated Justice Alito's Crawford concurrence. ${ }^{165} \mathrm{He}$ contended that interpreting the opposition clause to protect conduct that is less than active and purposive "would open the door to retaliation claims by employees who never expressed a word of opposition to their employers," i.e., silent opposition. ${ }^{166} \mathrm{He}$ warned that in some such cases the employee may be able to raise a triable issue of fact as to whether the employer indirectly learned of the opposition. ${ }^{167}$ Such cases, however, could be addressed on their facts. If the employee fails to allege sufficient facts to show an employer or decision maker was aware of that party's opposition, then the employee will not have a claim. Courts have not hesitated to grant judgment in favor of defendants where plaintiffs fail to demonstrate the employer was aware of the opposition. ${ }^{168}$ To deny coverage outright is contrary to the plain language of the statue, which, at most, requires only that employees oppose an unlawful employment practice, which unquestionably occurred in these cases. And in any event, employers in such instances cannot claim the opposition is silent as they, in fact, learn of it and cannot be held liable without proof of that knowledge. ${ }^{169}$

160. 339 F.3d 376 (5th Cir. 2003).

161. See id. at 381 .

162. See id.

163. See id. at $\mathbf{3 8 5}$.

164. See id.

165. See Crawford v. Metro. Gov't of Nashville \& Davidson Cnty., Tenn., 129 S. Ct. 846, 854 (2009) (Alito, J., concurring).

166. Id

167. See id.

168. See supra note 98.

169. See Pitrolo v. Cnty. of Buncombe, N.C., No. 07-2145, 2009 WL 1010634, at *3 (4th Cir. Mar. 11, 2009) (holding that despite the employer leaming of the plaintiff's opposition from a third party, plaintiff's claim was rejected). 
The next section considers the opposition clause in the context of the broader statutory scheme and purposes of Title VII. As explained below, the analysis further demonstrates that opposition contemplated by the statute is inconsistent with silent opposition.

\section{Expressive Opposition is Consistent with the Statutory Scheme and Purposes That Underlie It}

Title VII's anti-retaliation provision works in conjunction with its substantive provisions, which bar discrimination on the basis of certain protected categories. The statutory scheme and purposes that underlie it are more consistent with an expressive form of opposition that puts the employer on notice of employee opposition to potential workplace discrimination and simultaneously protects employees who provide such notice.

This section makes the case for interpreting the anti-retaliation provision in this manner, in part, by examining the Court's decisions in the area of sexual harassment. The Court has created an affirmative defense for employers in cases involving harassment by supervising employees. ${ }^{170}$ The Court has explained that the structure and purposes of Title VII animate that defense. ${ }^{171}$ In Crawford, the Court discussed the connection between its harassment defense and the opposition clause. ${ }^{172}$ It explained that the defense is meant to encourage employees to make employers aware of workplace discrimination. ${ }^{173}$ Further, once employers are made aware of such discrimination, the statute is designed to encourage employers to comply voluntarily with the statute's primary goal of eliminating workplace discrimination by promptly correcting it. ${ }^{174}$ Effectuating these goals requires an effective anti-retaliation provision that operates prior to an employee filing an EEOC charge. The opposition clause serves that purpose. ${ }^{175}$ That clause, therefore, is designed to protect employees who through words or conduct, action or inaction make employers aware of discrimination so that the latter fulfills its duty to correct it. ${ }^{176}$ As explained below, this scheme is

170. See Crawford, 129 S. Ct. at 852 .

171. See id. at $852-53$.

172. See id. at 852 .

173. See id.

174. Id.

175. See Sias v. City Demonstration Agency, 588 F.2d 692, 695 (9th Cir. 1978)

176. $I d$. 
inconsistent with silent opposition.

\section{External Investigations}

Title VII's substantive provision makes it an unlawful employment practice to discriminate on the basis of race, color, sex, national origin, or religion. ${ }^{177}$ The statute provides that an individual encountering discrimination based on a protected status may file or have filed on his or her behalf a charge of discrimination with the EEOC or an analogous state agency. ${ }^{178}$ The filing of the charge triggers certain statutory duties on the part of the EEOC. ${ }^{179}$ The agency must notify the employer of the charge and investigate the claim made to determine whether there is reasonable cause to believe the charge is true. ${ }^{180}$ If the investigation leads the EEOC to determine the charge is true, the next step contemplated under the statutory scheme is not litigation, but more informal means of resolving discrimination. ${ }^{181}$ The statute requires the EEOC to attempt to work with the employer to eliminate the discrimination through conference, conciliation, and persuasion. ${ }^{182}$

The purposes or goals of Title VII reinforce what the statutory language already suggests. The primary purpose of Title VII is to root out unlawful workplace discrimination. ${ }^{183}$ Allowing employees to bring claims of discrimination to the EEOC's attention for purposes of investigation, conciliation, and if necessary, litigation accomplishes that goal. The statute's structure shows that Congress never intended litigation to be the first line of defense to combat workplace discrimination. ${ }^{184}$ The statutory scheme and the primary purpose that underlies it of rooting out discrimination are effectuated through prompt investigation of complaints and informal correction via conciliation versus immediate resort to litigation. ${ }^{185}$

177. See Title VII of the Civil Rights Act of 1964, 42 U.S.C. $\S 2000 \mathrm{e}-2$ (a)(1)-(2) (2006).

178. See id. § $2000 \mathrm{e}-5(\mathrm{a})$.

179. See id. $\S 2000 \mathrm{e}-5(\mathrm{~b})$.

180. See id.

181. See id.

182. See id.

183. See EEOC v. Shell Oil Co., 466 U.S. 54, 77 (1984) ("The dominant purpose of [Title VII]

... is to root out discrimination in employment.").

184. See id. at 77 .

185. See 42 U.S.C. § 2000(e)-5(b); Shell Oil Co., 466 U.S. at 77. 


\section{Internal Investigations: Employer and Employee Obligations}

Courts typically hold that the opposition clause protects employees at points before a formal charge is filed. ${ }^{186}$ Such protection makes sense only if, as is the case, Congress intended to create an environment where employees would feel free to speak up about workplace discrimination in an effort to eliminate it. ${ }^{187}$ Accordingly, even before employees file an EEOC charge, Congress intended that employees could take their grievances to their employers without fear of reprisal. ${ }^{188}$ By encouraging employees to do so, Congress sought to provide employers an opportunity to investigate claims of discrimination and to root it out voluntarily without in the first instance having to defend itself before the EEOC or in a court action. ${ }^{189}$ That Congress intended to achieve Title VII's primary goal of eliminating workplace discrimination via employers and employees working together is evidenced by Title VII's history.

When Title VII was originally enacted, the EEOC's investigatory and enforcement authority was much more circumscribed than it is now because of Congress' desire that the statute would "encourage employers to comply voluntarily with the Act."190 It was only when Congress realized its desire was too optimistic that it enlarged the EEOC's authority. ${ }^{191}$ Congress, however, never abandoned its original desire to

186. See discussion supra Part II.A.

187. See Sias v. City Demonstration Agency, 588 F.2d 692, 695 (9th Cir. 1978)

188. See id. (interpreting opposition clause to protect employees who bring discrimination complaints to their employer's attention and noting that "[i]t should not be necessary for an employee to resort immediately to the EEOC or similar state agencies in order to bring complaints of discrimination to the attention of the employer with some measure of protection [and $t$ ]he resolution of such charges without governmental prodding should be encouraged"); see generally H.R. Rep. No. 914 (1990), reprinted in 1964 U.S.C.C.A.N. 2401 ("The purpose of [Title VII] is to eliminate, through the utilization of formal and informal remedial procedures, discrimination in employment based on of race, color, religion, or national origin.") (emphasis added).

189. See Sias, 588 F.2d at 695.

190. Shell Oil Co., 466 U.S. at 77. When Title VII was enacted, Congress granted the EEOC the authority to investigate charges of discrimination. See Title VII of the Civil Rights Act of 1964, Pub. L. 88-352, § 706(a), 78 Stat. 259 (1964) (codified as amended at 42 U.S.C. $§ 2000 \mathrm{e}-5$ (b)). If the EEOC determined that reasonable cause existed and that the employer discriminated against the employee, the agency's authority was limited to resolution by informal methods of conciliation, conference and persuasion. See id.

191. See Shell Oil Co., 466 U.S. at 77. The EEOC's enforcement authority was greatly expanded in 1972. See Equal Employment Opportunity Act of 1972, Pub. L. 92-261, § 4, 86 Stat. $103,124-28$ (1972) (codified as amended at 42 U.S.C. $\S 2000 \mathrm{e}-5$ ). 
have statutory violations remedied through informal means, ${ }^{192}$ including through voluntary employer compliance once the employer is made aware of possible discrimination. ${ }^{193}$

The goal of eliminating discrimination via informal means, however, would have been severely undermined if after being made aware of possible discrimination, the employer could have then punished employees for raising the issue. ${ }^{194}$ Indeed, failing to protect employees who report discrimination to their employers against retaliation might have actually spurred instead of reduced the need for government intervention and litigation as it would have forced employees to run to the EEOC in the first instance. ${ }^{195}$ Employees would have had absolutely no incentive to bring any claim to an employer's attention for informal resolution. ${ }^{196}$ As the Ninth Circuit recognized long ago, the opposition clause is necessary to encourage informal resolution of discrimination complaints without government meddling. ${ }^{197}$

The Supreme Court has recognized that Title VII's statutory scheme and the goals that underlie it—attempting to root out discrimination that comes to the employer's attention by informal methods-apply in the pre-charge context. This recognition has most notably arisen in the Court's sexual harassment jurisprudence. In Burlington Industries, Inc. v. Ellerth ${ }^{198}$ and Faragher v. City of Boca Raton, ${ }^{199}$ the Court addressed when an employee alleging hostile work environment sexual harassment by a supervisor under Title VII may hold an employer liable for that harassment. ${ }^{200}$

192. See Shell Oil Co., 466 U.S. at 77-78. According to the Court in Shell Oil Co., Congress' continued desire to have statutory violations remedied outside of the courts is evidenced by its requirement that if the EEOC finds reasonable cause that the employer has violated the statute, that it attempt to resolve the issue through conciliation. See id:; see also 42 U.S.C. $\S 2000 \mathrm{e}-5$ (b) ("If the [EEOC] determines after [its] investigation that there is reasonable cause to believe that the charge is true, the [EEOC] shall endeavor to eliminate any such alleged unlawful employment practice by informal methods of conference, conciliation and persuasion.")

193. See Sias, 588 F.2d at 695

194. See id.

195. See id.

196. See id.

197. See id.

198. 524 U.S. 742 (1998).

199. 524 U.S. 775 (1998).

200. At the outset, the article recognizes the shortfalls of the Burlington-Faragher affirmative defense and discusses them in the following section. See discussion infra Part IV.C. In part, because of the gaps in protection for victims of workplace harassment that result largely from the way lower courts have interpreted the Burlington-Faragher affirmative defense, this article argues that the active, purposive standard should be rejected as a threshold standard for actionable 
In Burlington and Faragher, the Court held that in the absence of a tangible employment action, ${ }^{201}$ an employer is entitled to an affirmative defense that would absolve it of liability. ${ }^{202}$ The Court held that a supervisor's harassing conduct should not be attributed to the employer when the employer can show: (1) it exercised reasonable care to avoid harassment and to correct it promptly when it might occur, and (2) the employee unreasonably failed to take advantage of those preventative or corrective opportunities or otherwise to avoid harm. ${ }^{203}$ The Court explained that the affirmative defense implements Title VII's statutory scheme and the purposes that underlie it. ${ }^{204}$

The Court, for instance, explained that while Title VII seeks to make persons whole for the injuries endured because of unlawful discrimination, the statute's principal objective is not to provide redress but to influence employer conduct, i.e., to encourage it not to discriminate in the first instance and promptly to correct discrimination when it learns of it. ${ }^{205}$ The affirmative defense is intended to assist this goal by encouraging conciliation between the employer and employee rather than litigation. ${ }^{206}$ It recognizes the employer's affirmative

opposition. See generally id. However, the discussion in this section is intended to demonstrate that the Court's discussion of the affirmative defense and the reasons for it further show that silent opposition is not contemplated by Title VII's anti-retaliation provision.

201. The Court defined a tangible employment action as "a significant change in employment status, such as hiring, firing, failing to promote, reassignment with significantly different responsibilities, or a decision causing a significant change in benefits." Burlington Indus., 524 U.S. at 761 .

202. See id. at 765; Faragher, 524 U.S. at 805 . Where the employee fails to show the employer took a tangible employment action, an employee may still establish a right to recover under a hostile work environment theory. See Pa. State Police v. Suders, 542 U.S. 129, 133 (2004). The plaintiff must show, among other things, that the harassment was "sufficiently severe or pervasive to alter the terms and conditions of [their] employment." See id. (quoting Meritor Savings Bank, FSB v. Vinson, 477 U.S. 57, 67 (1986)). In addition, there must be some basis to hold the employer liable. See id. The employer is not liable if it can prove the elements of the affirmative defense. See id. at 134.

203. See Burlington Indus., 524 U.S. at 765.

204. See Faragher, 524 U.S. at 805 ("This composite defense would, we think, implement the statute sensibly, for reasons that are not hard to fathom.").

205. See id. at 806 . The statute's preference for conciliation is evidenced by Congress' requirement that the EEOC investigate discrimination claims and seek to remedy them via informal means such as conciliation if the agency finds reasonable cause that discrimination exists. See Title VII of the Civil Rights Act of 1964, 42 U.S.C. $\$ 2000 \mathrm{e}-5$ (b) (2006).

206. See Burlington Indus., 524 U.S. at 764 ("Were employer liability to depend in part on an employer's effort to create [anti-harassment] procedures, it would effect Congress' intention to promote conciliation rather than litigation... and the EEOC's policy of encouraging the development of grievance procedures."). 
obligation to prevent statutory violations and gives credit when employers take reasonable efforts to discharge that duty by, for example, creating effective workplace anti-harassment policies. ${ }^{207}$ Requiring employees to bring harassment to an employer's attention and thus to avoid the harm of discrimination is borrowed from the general theory of damages, which requires a victim to avoid or minimize damages that result from violations of the statute. ${ }^{208}$ Harm of course is best avoided by allowing employees to report discrimination without fear of reprisal. ${ }^{209}$

In Crawford, the Court recognized the interplay between the affirmative defense in the harassment context and Title VII's antiretaliation provision. ${ }^{210}$ The employer in that case argued that employer liability should attach for retaliation only if an employee affirmatively reports discrimination to an employer and is then sanctioned for doing so. ${ }^{211}$ The defendant contended that employers should escape liability if they retaliate against an employee who merely reports harassment in response to an employer's question during an internal investigation of a discrimination complaint. ${ }^{21}$ According to the defendant, employers would have no incentive to investigate claims of discrimination if retaliation claims were easy. ${ }^{213}$ They would rather avoid the headache of investigating claims of discrimination because if they learn of discrimination, the employee who reports it and is later disciplined might allege retaliation. ${ }^{214}$

The Court found the argument nonsensical considering the "strong inducement" employers have by way of the Burlington-Farragher affirmative defense to uncover, prevent, and correct harassment. ${ }^{215}$ If an employer learns of harassment and fails to correct it promptly, it is subject to liability. ${ }^{216}$ It should not matter, therefore, how the employer

207. See Crawford v. Metro. Gov't of Nashville \& Davidson Cnty., Tenn., 129 S. Ct. 846, 852 (2009); see also Burlington Indus., 524 U.S. at 764.

208. See Faragher, 524 U.S. at 806 (citing Ford Motor Co. v. EEOC, 458 U.S. 219, 231 n.15 (1982)).

209. See Crawford, $129 \mathrm{~S}$. Ct. at 852 (noting that the statutory purpose of avoiding harm to employees would be severely undermined if employees could be penalized for answering employer questions about possible workplace discrimination).

210. See id.

211. See id. at $851-52$.

212. See id. at 850 .

213. See id. at 851-52.

214. See id. at 852 .

215. See id.

216. See Burlington Indus., Inc. v. Ellerth, 524 U.S. 742, 765 (1998). 
is made aware of possible harassment, either affirmatively or in response to a question. ${ }^{217}$ What matters is what employers do with that information-use it to correct harassment or to retaliate against the person reporting it. If the employer uses it for the latter purpose then it is not advancing one of the goals that animate the affirmative defense, that of incentivizing employers to ferret out and correct harassment.

The Court in Crawford explained that the employer and Sixth Circuit's rule would also undermine one of the statute's primary objectives of avoiding harm to employees. ${ }^{218}$ If employers could fire employees who report discrimination, then employees would have good reason to keep mum if asked by an employer about discrimination considering that they could be fired for reporting such offenses against themselves or others. $^{219}$

The structure of the statute and purposes underlying it, therefore, are at least in theory designed to encourage employees to bring their grievances forward to an employer's attention. The opposition clause assists in that goal by allowing the employee to raise the issue of discrimination with an employer before resorting to an administrative agency and ultimately litigation in an effort to avoid harm and work with the employer to stop its discriminatory practices. ${ }^{220}$ Neither the statutory scheme nor purposes that underlie it are consistent with silent or opinion opposition.

In sum, the anti-retaliation provision and the various concepts it encompasses are inconsistent with silent opposition. The term "has opposed" considered in isolation may refer to opinion or something broader. However, the term has typically been interpreted to refer to words or conduct from which opposition may be inferred, indicating the term as used in the statute refers to an expressive form of opposition. This interpretation is sound considering the explicit requirement that the employer be motivated by the opposition and the implicit requirement that the employer be aware of it. Finally, neither the structure nor purposes of Title VII are consistent with the concept of silent opposition.

With silence disposed of, the following section examines where to draw the line for actionable opposition under Title VII's anti-retaliation provision. In doing so, it demonstrates that the active, purposive

217. See Crawford, 129 S. Ct. at 852 .

218. See id.

219. See id.

220. Sias v. City Demonstration Agency, 588 F.2d 692, 695 (9th Cir. 1978). 
standard Justice Alito proposes is as untenable a standard as silence.

\section{StRIKING A BALANCE BETWEen Silent AND ACTIVE, PURPOSIVE OPPOSITION}

The active, purposive standard unnecessarily limits protection under the anti-retaliation provisions. There is a broad swath of activity that stands between silence and active, purposive conduct. A proper balance between silent opposition and the active, purposive form of opposition advocated by Justice Alito is to require some expression of opposition on the employee's part. Such expression may take many forms from disclosing it by words as the plaintiff in Crawford did, to conduct or even inaction, from which an employer may infer opposition, as is the case in the passive resistance cases. As long as the employee manifests opposition, the employer should be barred from discriminating on the basis of that manifestation.

To the extent the active, purposive standard is an effort to stave off claims where there is little to no proof that the employer learned of the opposition, the standard misses the mark. As explained, the lower courts have generally insisted that employees show that employers possessed actual knowledge of the employee's protected activity to allege an actionable retaliation claim. ${ }^{221}$ Thus, the standard goes too far to protect employers against retaliation claims arising under the opposition clause "by employees who never expressed a word of opposition to their employers." 222 Moreover, the active, purposive standard is ill-advised for several other reasons.

\section{A. The Standard is Inconsistent with the Plain Language of the Statute}

The plain language of the anti-retaliation provision bars employers from retaliating against employees for the latter's opposition to discrimination. $^{223}$ The statutory language is unambiguous. ${ }^{224}$ The

221. See supra note 98 and accompanying text.

222. See Crawford, 129 S. Ct. at 854 (Alito, J., concurring).

223. See Title VII of the Civil Rights Act of 1964, 42 U.S.C. $\S 2000 \mathrm{e}-(3)$ (a) (2006).

224. The issue here is not whether a word or phrase in the statute is ambiguous and could be interpreted as imposing an intent requirement on the employee. Cf. Dolan v. U.S. Postal Serv., 546 U.S. 481, 485-86 (2006) (determining whether the statutory term "negligent transmission of mail" is ambiguous by using methods of statutory interpretation); Robinson v. Shell Oil Co., 519 U.S. 337, 340-41 (1997) (considering whether the word "employee" might encompass former employees). 
statute imposes no intent requirement on the employee but only on the employer, which may not discriminate against the employee on the basis of that opposition. Thus, an employee is not required to oppose discrimination for any particular purpose, such as to end or prevent it as the active, purposive standard requires. ${ }^{225}$ As long as the employee manifests an expression of opposition, the statute requires no more of that employee. If the employer discriminates against the employee based on that expression, the employee may assert a retaliation claim.

\section{B. The Standard Ignores the Possibility of Unintentional Opposition}

Because the focus of opposition is properly placed on whether, rather than on how the employer learns of it, an employee may also manifest opposition unintentionally. The EEOC has long interpreted Title VII as permitting unintentional opposition. ${ }^{226}$ According to the EEOC, if an employee's conduct is interpreted by an employer as opposing an unlawful practice and the employer retaliates on the basis of its own interpretation, the employer has violated Title VII's antiretaliation provisions. ${ }^{27}$ An employee in these circumstances may not even be aware he or she is sending a message of opposition to a

Rather, the active, purposive standard is an attempt to read language into the statute that is plainly not there. The Court has rejected such attempts in other contexts. See, e.g., Domino's Pizza, Inc. v. McDonald, 546 U.S. $470,479-80$ (2006) (holding that 42 U.S.C. $\$ 1981$ required person stating cause of action to have a contractual relationship with defendant and plain text did not support plaintiff's claim where he had no such contractual relationship with defendant but only acted as an agent for the corporation that did have such a relationship; the Court rejected plaintiff's policy arguments that contradicted the plain text of statute); Desert Palace, Inc. v. Costa, 539 U.S. 90, 9899 (2003) (rejecting argument that a plaintiff is entitled to a mixed-motive jury instruction only upon presenting "direct evidence" of discrimination; statute "on its face" imposes no such requirement on the plaintiff to receive a mixed-motive instruction, and if Congress had intended to impose such a requirement, "it could have made its intent to do so clear by including language to that effect" in the statute).

225. While requiring the employee to bring the discrimination to the employer's attention for the specific purpose of ending it might effectuate the statutory goal of avoiding harm, for other reasons explained in this section, the rule is not only contrary to the language of the statute but undermines other goals of Title VII. See discussion infra Part IV.D.

226. See EEOC Decision No. 71-345, 2 Fair Empl. Prac. Cas. (BNA) 1083, 1084 (Oct. 13, 1970) (determining that reasonable cause existed that employer violated Title VII when it fired employee for referring black applicant to employer; employee's referral unintentionally served as opposition to employer's unwritten policy of not hiring black females and employee's discharge resulted from her inadvertent opposition).

227. See id. (The purpose of the retaliation provision would be "defeated if employers could with impunity retaliate against employees for behavior which unintentionally has the effect of opposing" an unlawful employment practice). 
potentially unlawful employment practice. However, if the employer nevertheless infers or interprets such a message and discriminates on that basis, the anti-retaliation provision is violated. ${ }^{228}$

Courts also have held that an employer may retaliate against an employee because it reasonably believed that the employee engaged in protected activity although the employee had not done so at all. ${ }^{229}$ The critical issue is whether the employer infers or interprets opposition from the employee's expression and discriminates on that basis. This reading is consistent with the statute's language, which bars employers from retaliating because of employee opposition. ${ }^{230}$ If the employer discriminates because it wrongly believes the employee was engaging in opposition, the employer still discriminates on the basis of the employee's expression of opposition. ${ }^{231}$ The employee's intent to oppose is therefore irrelevant; the relevant inquiry is what the employer intends.

Further, permitting employers to retaliate against employees based on what the employer reasonably believes to be opposition to alleged unlawful discrimination (although the employer was wrong because the employee did not intend to oppose any practice) would undermine the statute's goals. When the employer is made aware that discrimination may exist or is being complained of, it should seek to resolve it. By doing so, it effectuates the statutory goals of self-correction, conciliation, and rooting out discrimination that animate Title VII. If instead of using the information it gleans from an individual to investigate and eliminate

228. See id.

229. See Fogleman v. Mercy Hosp., Inc., 283 F.3d 561, $571-72$ (3d Cir. 2002) (holding that plaintiff who did not actually engage in protected activity but who was allegedly retaliated against because he was perceived to have engaged in such activity stated a retaliation claim under the ADEA. The statute focuses on employer's specific intent to discriminate and the fact that employee did not actually engage in protected activity but was perceived to have done so and was discriminated against on that basis states a claim for retaliation); Grosso v. City Univ. of N.Y., No. 03 Civ. 2619NRB, 2005 WL 627644, at *3 (S.D.N.Y. Mar. 16, 2005).

230. See Title VII of the Civil Rights Act of 1964, 42 U.S.C. $\$ 2000 \mathrm{e}-3$ (a) (2006).

231. See Fogleman, 283 F.3d at 571-72. A short example demonstrates this point. For instance, an employee may manifest opposition by attending an event for informational purposes only, but is staged by others to challenge an employer's discriminatory practices of not hiring women. Although the employee may not intend to send a message of opposition to that practice by attending the meeting (but is there only to gather information) that person's attendance may reasonably send such a message. $C f$. id. (holding that plaintiff who did not actually engage in protected activity but who was allegedly retaliated against because he was perceived to have engaged in such activity stated a retaliation claim under the ADEA. The statute focuses on employer's specific intent to discriminate.); Grosso, 2005 WL 627644, at *3 (employing same analysis under Title VII). 
the alleged discrimination, it opts to retaliate instead, the employer undermines these statutory goals and should be held in violation of the anti-retaliation provisions. As long as the employee manifests an expression of opposition to the alleged unlawful employment discrimination, the employer should be prohibited from discriminating against the employee on that basis.

The employer's duty under Title VII to root out discrimination is a primary reason the active, purposive standard misses the mark. ${ }^{232}$ It is true that requiring an employee to affirmatively report discrimination to the employer may effectuate the statutory goal of avoiding harm on the employee's part. It would serve to put the employer on notice of possible discrimination so that the employer could remediate it-clearly a goal of Title VII. However, limiting protection unnecessarily to those instances minimizes the importance of the employer's duty to investigate, selfcorrect, and engage in conciliation. To that end, whether the employer suspects possible discrimination by words or reasonable inference from conduct or inaction, the employer should have a duty to investigate and extirpate the discrimination if it exists. If the employer could reasonably understand that the employee opposes an alleged discriminatory practice, but uses that knowledge to retaliate against the employee, the anti-retaliation provision is violated just as certainly as if the employee had marched into the employer's office and stated opposition against the employer's discriminatory practices.

\section{The Standard Compounds Gaps in Protection Afforded in Workplace Harassment Law}

Scholars have noted that the law governing workplace harassment, particularly the Burlington-Faragher affirmative defense, ${ }^{233}$ leave serious gaps in protection for victims of unlawful harassment. ${ }^{234}$ As explained below, the active, purposive standard would only exacerbate

232. See Crawford v. Metro. Gov't of Nashville \& Davidson Cnty., Tenn., 129 S. Ct. 846, 854 (2009) (Alito, J. concurring). Under this standard, an employee is not protected against retaliation unless the employee specifically intended to bring the opposition before an employer for the purpose of ending, preventing, redressing, or correcting unlawful discrimination. See id.

233. See discussion supra Part III.C.2.

234. See Brake \& Grossman, supra note 28, at 879 (explaining that lower courts interpreting the affirmative defense have taken an anti-employee view); Lawton, supra note 28 , at 212 (contending that it is questionable whether the affirmative defense was the best method to achieve Title VII's goal of preventing workplace harassment). 
those gaps. ${ }^{235}$

Although the Court has interpreted Title VII's anti-retaliation provision broadly, it acknowledged in Crawford that fear of reprisal was the primary reason discrimination often goes unreported. ${ }^{236}$ Scholars also have noted that with sexual harassment in particular, ${ }^{237}$ employees are hesitant to report discrimination through formal means because those that do fear being (and often are) labeled hypersensitive or troublemakers. ${ }^{238}$ In fact, filing a formal discrimination complaint is the least likely response for women who are victims of sexual harassment. ${ }^{239}$ The social costs of being stamped with the troublemaker badge and fear of retaliation are the primary reasons women do not complain about harassment. Rather than complaining formally, victims are more likely to deal with harassment in other ways, such as sharing their experiences with friends and coworkers or seeking an out, for instance, by transfer or absenteeism. $^{240}$ The law of sexual harassment does not take these workplace realities into account.

Because of the fear of reporting harassment, victims either fail to report it or delay doing so, derailing their sexual harassment claim. That

235. It would only further add to what Professors Deborah Brake and Joanna Grossman have called the failure of Title VII as a system for claiming discrimination rights. See generally Brake \& Grossman, supra note 28, at 861-66 (explaining how prompt complaint doctrines, including the Burlington-Faragher affirmative defense and other rules imposed on plaintiffs asserting employment discrimination, have served as barriers to plaintiffs claiming rights under Title VII).

236. See Crawford, 129 S. Ct. at 852 (citing Deborah L. Brake, Retaliation, 90 MINN. L. REV. $18,20,37 \&$ n.58 (2005)).

237. See Brake \& Grossman, supra note 28, at 896 ("The best data about how employees actually respond to discrimination come in the sexual harassment context because only there does the law officially require internal grievances as a prerequisite to vindicating rights.").

238. See id. at 900 (explaining that social psychologists find that women and people of color who challenge workplace discrimination are perceived to be troublemakers or hypersensitive); see also Anne Lawton, Between Scylla \& Charybdis: The Perils of Reporting Sexual Harassment, 9 U. PA. J. LAB. \& EMP. L. 603, 605-06, 616 (2007). According to Professor Lawton, women typically face skepticism when alleging harassment. See id. at 616. The "dominant perception" is that they are lying, attempting to gain some type of advantage by lodging the complaint or are being hypersensitive. See id.; see also Long, supra note 2, at 933 ("Individuals who complain about workplace discrimination are frequently labeled as troublemakers by those in positions of authority within the organization.").

239. See Brake \& Grossman, supra note 28 , at 899.

240. See id. at 899; see also Taylor v. Solis, 571 F.3d 1313, 1317 (D.C. Cir. 2009) (explaining that months before formally complaining about harassment through her employer's formal procedure, employee confided in a coworker, who was a management employee though not her supervisor); Baldwin v. Blue Cross/Blue Shield of Ala., 480 F.3d 1287, 1295 (11 th Cir. 2007) (explaining that before resorting to employer's formal harassment policy, the employee shared alleged harassment with her secretary and other coworkers because she contended she wanted nothing in her employee file that might harm her future chances for promotion). 
result is grounded in the way courts have interpreted the BurlingtonFaragher affirmative defense. That standard allows an employer an affirmative defense to a claim of supervisor hostile work environment sexual harassment, where it can show (1) it had an effective mechanism in place, and (2) the employee unreasonably failed to take advantage of that mechanism or to avoid harm otherwise. ${ }^{241}$ If an employer makes both showings, courts typically grant judgment in their favor on liability. ${ }^{242}$ Proof that the employer has an "effective" anti-harassment policy in place generally satisfies the first prong of the affirmative defense. $^{243}$

The second prong of the affirmative defense has become a stumbling block to plaintiffs who have been sexually harassed for several reasons. First, the lower courts often reject harassment claims where the employee fails to report the harassment promptly. The employee's delay demonstrates that the employee unreasonably failed to take advantage of the employee's reporting procedure or to avoid harm otherwise. ${ }^{244}$ The lower courts have interpreted whether a complaint is prompt rather strictly against plaintiffs. ${ }^{245}$ For instance, a two- to threemonth delay between an initial incident of harassment and the official complaint is commonly found to be unreasonable, ${ }^{246}$ although shorter time periods have also been considered unreasonable as a matter of law as well. ${ }^{247}$

241. See Faragher v. City of Boca Raton, 524 U.S. 775, 807 (1998); Long, supra note 2, at 952.

242. See Long, supra note 2, at 952.

243. See Lawton, supra note 28, at 214-15. Courts have found that an "effective" harassment policy contains several features, including (1) the ability for the victim to bypass the harasser in reporting the harassment; (2) a statement that a complaint will be investigated promptly; (3) a statement explaining that the victim will not be retaliated against for the complaint; and (4) a statement that complaints will be kept as confidential as possible under the circumstances. See Barrett v. Applied Radiant Energy Corp., 240 F.3d 262, 266 (4th Cir. 2001) (listing the aforementioned factors as indicative of a reasonable policy).

244. See Taylor, 571 F.3d at 1319; Baldwin, 480 F.3d at 1307; Walton v. Johnson \& Johnson Servs., 347 F.3d 1272, 1289-91 (11th Cir. 2003).

245. See Brake \& Grossman, supra note 28 , at 879 ("Lower courts interpreting the affirmative defense have taken a particularly anti-plaintiff view of the second prong for determining whether a delay in filing a complaint was excessive or whether the failure to file a complaint was reasonable.").

246. See Baldwin, 480 F.3d at 1307 (three-month delay between first incident of harassment and complaint was unreasonable as a matter of law); Walton, 347 F.3d at 1289-91 (two-and-a-half month delay too long); cf. Taylor, 571 F.3d at 1319 (holding that five-month delay between harassment that began in fall 2001 and reported the following April was unreasonable as a matter of law and citing Baldwin approvingly, where three-month delay was held to be unreasonable).

247. See Conatzer v. Med. Prof'l Bldg. Servs., Inc., 255 F. Supp. 2d 1259, 1270 (N.D. Okla. 
Professor Anne Lawton explains that the law treats a delay in reporting harassment as a proxy for the victim's veracity. ${ }^{248}$ In general, the view is that if the harassment were so terrible, the victim would have reported it right away. ${ }^{249}$ However, prompt reporting is a poor proxy for credibility, considering that most employees fail to report harassment in fear of being labeled a troublemaker or experiencing retaliation and not because they are lying about the harassment. ${ }^{250}$ Victims tend to believe that if they report the discrimination, their situations might worsen. ${ }^{251}$ However, courts typically hold that an employee's generalized fear of retaliation is insufficient to excuse a failure to promptly report harassment. ${ }^{252}$

The second way in which the affirmative defense has derailed otherwise viable harassment claims is when plaintiffs, who reported the discrimination to someone other than the designated individuals contained in the employer's policy, are found to have acted unreasonably for purposes of the Burlington-Faragher affirmative defense. $^{253}$ The law allows employers to satisfy the first prong of the

2003) (holding that a seventeen-day delay between first significant incident of harassment and complaint was unreasonable). Professor Anne Lawton has argued persuasively that courts have turned the second inquiry into a per se reasonableness inquiry based on whether the plaintiff reported or did so immediately after the first incident of harassment. See Lawton, supra note 28, at 215-16. By doing so, courts fail to evaluate the reasonableness of the plaintiff's actions in the context of the specific case and the empirical evidence showing that victims tend not to initially respond to harassment by lodging a formal complaint. See id.

248. See Lawton, supra note 238, at 618.

249. See id; see also Frazier v. Tenn. Dep't of Corrs., No. 3:07-0818, 2008 WL 2781665, at *7 (M.D. Tenn. July 14, 2008) (holding that compliant made three months after first incident of racial harassment and four days after second incident might give the jury pause in determining whether the incidents were as serious as plaintiff contends).

250. See Lawton, supra note 238 , at 618-19.

251. See id.

252. See Long, supra note 2, at 953 . If the fear is grounded on a specific basis, the failure to report may be excused. See id. Even when the fear is supported by some proof a court may still find the fear to be unwarranted. See, e.g., Barrett v. Applied Radiant Energy Corp., 240 F.3d 262, 267-68 (4th Cir. 2001) (holding that plaintiff's fear of retaliation found unwarranted although she alleged that two of her employer's managers had sexually harassed other employees in the past and had not been disciplined).

253. See, e.g., Taylor v. Solis, 571 F.3d 1313, 1319 (D.C. Cir. 2009) (noting that report of harassment complaint to management employee was unreasonable because policy required employee report harassment to a company EEO counselor or EEO manager); Ogden v. Keystone Residence, 226 F. Supp. 2d 588, 601-02 (M.D. Pa. 2002) (explaining that plaintiff acted unreasonably in mentioning alleged harassment to her supervisors when she failed to ask them to follow up and failed to follow her employer's complaint procedure to report harassment to human resources specialist or to bring her complaint to the attention of senior management); Mukaida v. Hawaii, 159 F. Supp. 2d 1211, 1232 \& n.14, 1233 (D. Haw. 2001) (holding that plaintiff failed to 
affirmative defense despite having a narrow list of persons to which official complaints may be reported. ${ }^{254}$ Further, as to the second prong, unless employees complain only to the persons contained on the list, they are often found not to have acted reasonably in taking advantage of the employer's procedures or otherwise avoiding harm. ${ }^{255}$

If employers and courts were serious about achieving Title VII's primary goal of eliminating workplace discrimination, employers could allow those employees who believe they have been victims of harassment to report their belief to any supervisory or management employee and put the burden on those employees to report complaints to the internal department that investigates such complaints. ${ }^{256}$ Courts should consider whether an employer who fails to issue such a directive to its management employees has acted reasonably to prevent and correct harassment. Forcing employees to follow a rigid employerimposed guideline regarding reporting harassment places form over substance when the employee has in fact reported the harassment to a management or supervisory employee although not one designated in the employer's official policy.

The active, purposive standard compounds the aforementioned gaps existing in workplace harassment law. An employee who fails to complain promptly or to an individual not designated in the employer's policy would likely lose on her sexual harassment claim. By imposing an active, purposive standard on retaliation claims, the employee also would be unable to challenge retaliation that may occur after the employee complained, even though he or she had no intent to do so to end, correct, or remediate the harassment. The active-purposive standard would give employers carte blanche to retaliate against employees who fail to complain purposively about harassment even though the reason that victims often fail to actively complain is to avoid the retaliation that often accompanies such a complaint. An employee

\footnotetext{
act reasonably in reporting alleged harassment by complaining to her supervisor although he was not designated in her employer's reporting procedure to receive complaints); Green v. Wills Group, Inc., 161 F. Supp. 2d 618, 626 (D. Md. 2001) (holding that plaintiff's earlier reports of harassment to another employee was not notice to employer as the report was not in conformance with employer's stated policy, which provides for notice to the human resources department).

254. See Lawton, supra note 28, at 214-15.

255. Mukaida, 159 F. Supp. 2 d at 1232 \& n.14.

256. Some employers adopt such an approach. See Barrett, 240 F.3d at 266 (describing company policy as allowing an employee who has encountered harassment to "contact any member of the management team, male or female, with whom [the employee] feels comfortable discussing the situation") (internal quotation marks omitted).
} 
who fails to actively or purposively complain may face both harassment and retaliation, but would be unable to claim any rights under the statute. ${ }^{257}$

In Crawford, the Court recognized the interplay between the Burlington-Faragher affirmative defense and Title VII's anti-retaliation provision. ${ }^{258}$ In doing so, the Court refused to interpret the opposition clause in a manner that may have made it less likely that employees would report harassment to their employers. ${ }^{259}$, The Supreme Court's interpretation of the anti-discrimination law, including the BurlingtonFaragher affirmative defense, seeks to encourage employees to report discrimination. However, this interpretation has the effect of punishing those employees who fail to act in this manner. When an employer is informed of potential harassment even indirectly and non-purposively, its duty should be to investigate and eliminate the discrimination, not to compound the problem by engaging in the very retaliation the employee feared which led the employee to make an indirect complaint in the first place. The Burlington-Faragher affirmative defense would eliminate the possibility of a harassment claim in these circumstances. To that end, the active-purposive standard further undermines Title VII's goal of rooting out workplace discrimination because employers would be free to retaliate against employees for indirect, non-purposive complaints. Employers would have little incentive not to retaliate in such instances. Conceivably, as long as the employer can show the plaintiff failed to report harassment purposively, promptly, or to a particular set of individuals designated in the employer's harassment policy, then regardless of the plaintiff's injury, his or her claims for harassment and retaliation experienced for a complaint received about that harassment would fail.

\section{The Active-Purposive Standard is Premised on Irrelevant Policy Concerns}

A troubling aspect of the push by Justice Alito to require opposition conduct that is active and purposive is that it appears to be motivated by

257. See generally Wills Group, 161 F. Supp. 2d at 626 (regarding an employee that faced retaliation after attempting to complain of harassment to another employee).

258. See Crawford v. Metro. Gov't of Nashville \& Davidson Cnty., Tenn., 129 S. Ct. 846, 852 (2009).

259. See discussion supra Part III.C. 
courts' expanding dockets. ${ }^{260}$ In his Crawford concurrence, Justice Alito argued that "[a]n expansive interpretation of protected opposition conduct would likely cause the [recent spike in retaliation claims] to accelerate."261 The obvious response to that concern, however, is that Congress, not the courts, should decide how far to extend the antiretaliation provision. Congress drafted a statute that grants protection if an employee opposes a practice made unlawful under Title VII. The statutory language does not impose an intent requirement on the part of the employee at all. The only intent requirement falls on the employer, which may not intentionally retaliate against the employee because of the latter's opposition. ${ }^{262}$

Courts have no business relying on irrelevant policy concerns to promulgate prophylactic rules that narrow a statute's plain language. ${ }^{263}$ That approach is particularly inappropriate with regard to remedial legislation, which should be interpreted broadly to effectuate the purposes of the statute. ${ }^{264}$

The anti-retaliation provision protects an employee from retaliation because that individual "has opposed" an unlawful employment practice. When the employee does so whether in response to an employer's question (as in Crawford) or by some other form of expression, the employee should be protected by the statute's anti-retaliation provision. This discussion is not intended to set limits on actionable opposition conduct under the opposition clause. The discussion shows, however, that the opposition clause contemplates more than unexpressed opinion but is consistent with opposition in its more expressive forms.

260. See Crawford, $129 \mathrm{~S}$. Ct. at 855 (Alito, J., concurring) (noting that the number of retaliation claims filed with the EEOC "has proliferated in recent years").

261. Id.

262. See Title VII of the Civil Rights Act of 1964, 42 U.S.C. $§ 2000$ e(3) (2006).

263. Cf. Brogan v. United States, 522 U.S. 398, 408 (1998) ("Courts may not create their own limitations on legislation, no matter how alluring the policy arguments for doing so."); City of L.A. Dep't of Water \& Power v. Manhart, 435 U.S. 702, 708-09 (1978) (noting that an employer's policy discriminated against women employees, and thus the Court refused to rely on a policy argument of "fairness" to allow the employer to discriminate against women based upon generalizations).

264. See Sutton v. United Air Lines, 527 U.S. 471, 504 (1999) (Stevens, J., dissenting) (quoting Techerepnin v. Knight, 389 U.S. 332, 336 (1967) ("It has long been a "familiar canon of statutory construction that remedial legislation should be construed broadly to effectuate its purposes."')), 


\section{Protecting Miriam}

Crawford considered the full breadth of the term oppose and all its possible meanings. However, considering the statutory language, context, scheme, and purpose, the term "oppose" as used in the statute does not envision silent, unexpressed opposition. ${ }^{265}$ That said, determining how to interpret the term does not mean imposing an unnecessarily high bar to retaliation claims, particularly considering their importance in uncovering and eliminating unlawful workplace discrimination. The active, purposive standard is an unnecessarily high bar for a successful retaliation claim.

The concerns Justice Alito raises in his concurrence about silent opposition do not withstand scrutiny. Without proof of actual knowledge of the employee's protected activity, it is doubtful at best that an employee's retaliation claim would survive. Moreover, this high bar shuts off claims where the employer undisputedly learns of the opposition. The hypothetical set forth in the introduction, which is loosely based a composite of cases employing the active, purposive standard, proves the point. In that hypothetical, Miriam is harassed by her supervisor, but she does not complain directly to her employer. Instead she voices her complaint to a friend and coworker, who is also a management employee of the company, who, in turn, passes the complaint on to human resources, the department that investigates complaints.

A successful harassment claim on these facts is doubtful considering Miriam failed to follow her employer's established procedure. ${ }^{266}$ Her retaliation claim should fare better under the statute. She expressed opposition, which was communicated to her employer. Title VII requires no more and thus neither does Crawford. ${ }^{267}$ According to the Court " $[w]$ hen an employee communicates to her employer a belief that the employer has engaged in . . . a form of

265. Of course, not all silence is the same. For instance, silence in response to an illegitimate demand for speech is protected as expressive conduct under the First Amendment. See Wooley v. Maynard, 430 U.S. 705, 714 (1977) (reasoning that the right of freedom of thought protected by the First Amendment against state action includes the right to speak freely and the right to refrain from speaking at all). Crawford recognized that expressive conduct in its many forms is protected under the opposition clause by recognizing passive resistance as a viable form of opposition. See Crawford, 129 S. Ct. at 851 . Such silence is expressive and communicative. See id.

266. See discussion supra Part IV.C.

267. See Crawford, 129 S. Ct. at 851 ("[W]e would naturally use the word [oppose] to speak of someone who has taken no action at all to advance a position beyond disclosing it."). 
employment discrimination, that communication virtually always constitutes the employee's opposition to the activity." "268 The Court did not hold that this rule applies only when opposition is "directly" communicated $^{269}$ to employers or to those instances where the employee intends to communicate opposition for a delineated purpose. ${ }^{270}$ That Miriam's complaint may be considered non-purposive should have no bearing on the success of her claim.

Pre- and post-Crawford, some courts, however, have rejected this broad reading of the anti-retaliation provision and endorsed the active, purposive standard. ${ }^{271}$ Limiting actionable opposition in this manner ignores the statute's plain language, undermines the purpose of the opposition clause to protect employees who complain about discrimination in informal, workplace settings, and allows employers fully aware of the opposition to ignore their obligation to investigate the complaint for veracity and, if true, engage in self correction-a result at odds with the statute's purposes.

\section{CONCLUSION}

Relying on Title VII's broadly worded anti-retaliation provision, the Court in Crawford rejected active, demanding standards for opposition conduct to be actionable. As long as the employee expresses opposition to alleged unlawful employment discrimination that is communicated to the employer, the latter is prohibited from discriminating against the employee on the basis of the expression.

268. Id. (quotations omitted).

269. The plaintiff in Crawford communicated her complaint directly to her employer. See Crawford, $129 \mathrm{~S}$. Ct. at 850-51. However, the Court's statement that "[w]hen an employee communicates to her employer a belief that the employer has engaged in . . . a form of employment discrimination, that communication virtually always constitutes the employee's opposition to the activity," could be read at least two ways. $I d$. at 851 . It could mean the employee must always communicate opposition directly to the employer. Or, it could mean that after the employee communicates opposition, and the employer learns of it, the employee still communicates her opposition to her employer. See id. The Court's statement, therefore, does not preclude indirect communication of opposition. See id.

270. See id.

271. See Pitrolo v. Cnty. of Buncombe, N.C., No. 07-2145, 2009 WL 1010634, at *3 \& n.6 (4th Cir. Mar. 11, 2009); see also Ackel v. Nat'l Commc'n Inc., 339 F.3d at 376, 385 (5th Cir. 2003) (holding that plaintiff had not engaged in protected activity when she was fired after complaining of discrimination to a coworker, who in turn informed the company's general manager and president after plaintiff neither complained on her own nor asked her coworker to act on her behalf). 
Crawford focused on whether an employer becomes aware of opposition rather than how it becomes aware of it. Nothing in Crawford suggests that such communication may not be indirect. Moreover, opposition may be unintentional. Congress imposed an intent requirement only on employers, who may not intentionally retaliate against an employee for opposition. Neither Congress nor (consistent with the statute's plain language) the Court in Crawford imposed an intent requirement on the employee. All courts have not yet embraced this expansive reading of the opposition clause as evidenced by courts adopting the active, purposive requirement suggested by Justice Alito in his separate concurring opinion. This failure brings to mind the adage, you can lead a horse to water, but you can't make him drink. Crawford has opened these doors, but it is up to the lower courts or perhaps the Supreme Court in a subsequent decision to walk through them. 